\title{
Review
}

\section{Oncolytic viral therapies}

\author{
Eugene Lin, ${ }^{1}$ and John Nemunaitis ${ }^{1,2,3}$ \\ ${ }^{1}$ Mary Crowley Medical Research Center, Dallas, Texas, USA; ${ }^{2}$ US Oncology, Dallas, Texas, USA; and \\ ${ }^{3}$ Baylor University Medical Center, Dallas, Texas, USA.
}

Molecular research has vastly advanced our understanding of the mechanism of cancer growth and spread. Targeted approaches utilizing molecular science have yielded provocative results in the treatment of cancer. Oncolytic viruses genetically programmed to replicate within cancer cells and directly induce toxic effect via cell lysis or apoptosis are currently being explored in the clinic. Safety has been confirmed and despite variable efficacy results several dramatic responses have been observed with some oncolytic viruses. This review summarizes results of clinical trials with oncolytic viruses in cancer.

Cancer Gene Therapy (2004) 11, 643-664. doi:10.1038/sj.cgt.7700733

Published online 30 July 2004

\section{Keywords: oncolytic; malignancy; virus}

$\mathrm{O}$ ncolytic viruses, which have been tested as cancer therapeutics, have either been naturally selected or have been genetically engineered to grow specifically in and kill tumor cells. Specificity to cancer is derived by exploiting cell surface or intracellular aberrations in gene expression that rise in malignancies during tumor evolution. ${ }^{1}$ Adenoviruses are the most widely studied engineered oncolytic viruses in the clinic. These adenoviral constructs include Onyx 015, ${ }^{2,3}$ CG7060, ${ }^{4}$ CG7870, d1922-947, ${ }^{6}$ Ad5-CD/tk-rep, ${ }^{7}$ Ad-delta24, ${ }^{8}$ Ad DF3-E1, ${ }^{9}$ Onyx 411, ${ }^{10}$ OAV001, ${ }^{11} \mathrm{KD} 3,{ }^{12}$ and 01/PEME. ${ }^{13}$

Historically, evidence of oncolytic activity attributed to replicating viruses was provided in published case reports as early as 1912. These reports described rare but dramatic responses in cancer patients recovering from viral syndromes. ${ }^{14-28}$ Based on these observations, viruses with low pathogenicity (minimal toxicity to normal tissue) and high oncolytic capacity (toxic to cancer cells) were selected for initial clinical investigation. ${ }^{28-34}$ Studies in the 1950s with Egypt 101 virus revealed anticancer activity in the form of transient tumor necrosis in patients. However, further studies were discontinued when immune compromised patients developed encephalitis. ${ }^{35-37}$ Later attenuated mumps virus was tested in cancer patients and more impressive anticancer activity was observed. Responses, however, were generally transient, and they were limited to the site of injection. ${ }^{30,31,38-41}$ In an attempt to pursue a more systemic approach following local site injection methods of stimulating the immune system using viral "oncolysates" were developed. Researchers exposed virus to malignant cells ex vivo, induced oncolysis thereby

\footnotetext{
Received January 2, 2004.

Address correspondence and reprint requests to: Dr John Nemunaitis, MD, 3535 Worth Street, Collins Bldg., 5th Floor, Dallas, TX 75246,USA. E-mail: John.Nemunaitis@USOncology.com
}

providing antigenic material that could be used as a vaccine. Influenza viral "oncolysates" induced greater antitumor activity in vivo than either virus alone or unmodified tumor cell extracts. ${ }^{42,43}$ In one trial involving patients with advanced ovarian cancer, a subset of patients demonstrated durable responses, which appeared to be enhanced following treatment with interleukin-2 (IL-2). ${ }^{44}$ Other studies utilized a Newcastle disease viral (NDV) oncolysate and demonstrated impressive survival improvement in early melanoma patients compared to historical controls $(69 \%$ disease-free survival at 10 years versus $15 \%$ disease-free survival). Currently, a modified Newcastle disease virus (73T) is being utilized as a vaccine oncolysate in an ongoing clinical trial involving melanoma and renal cell patients. Preliminary results appear encouraging. ${ }^{45}$

This review will focus on the anticancer activity of oncolytic viruses when administered directly to the patient. Discussion will center on clinical trial results, future directions, and the potential use of oncolytic viruses as safe and systemic gene delivery vehicles.

\section{Onyx 015}

Onyx 015 is a replication-conditional adenovirus genetically modified by deletion of two DNA elements. Deletion of the first element, the E1B $55 \mathrm{kDa}$ fragment, enables replication of Onyx 015 in cells with a defective p53 pathway (cancer cells) $)^{2,46,47}$ and minimizes replication in cells with a functional p53 pathway (normal cells). Some controversy exists on whether or not the sole mechanism by which Onyx 015 has selective replication capacity in malignant cells is related to $\mathrm{p} 53 .^{48-51}$ However, despite controversy most preclinical results do demonstrate 
Table 1 Clinical trials involving Onyx 015

\begin{tabular}{|c|c|c|c|c|c|}
\hline Design & No. of patients/disease & Toxicity & Response & Comments & Reference \\
\hline $\begin{array}{l}\text { Phase I: } 5 \text { daily consecutive } \\
\text { injections over } 3 \text { weeks } \\
\text { Doses up to } 2 \times 10^{12} \text { particles }\end{array}$ & $22 / \mathrm{SCCHN}$ & Transient fever & $3 \mathrm{PR}, 2 \mathrm{MR}, 8 \mathrm{SD}$ & $\begin{array}{l}\text { Tumor necrosis induced in patients } \\
\text { characterized with SD }\end{array}$ & Ganly et a $\left.\right|^{59}$ \\
\hline $\begin{array}{l}\text { Phase II: } 2 \times 10^{11} \text { particles } \\
\text { I.t. injection (every day } \times 5 \text { days } / 3 \\
\text { weeks) }\end{array}$ & $30 / \mathrm{SCCHN}$ & $\begin{array}{l}\text { Transient fever, chills, asthenia, } \\
\text { injection pain }\end{array}$ & $1 \mathrm{CR}, 3 \mathrm{PR}, 12 \mathrm{SD}$ & $\begin{array}{l}7 / 12 \text { patients with p53 mutation } \\
\text { developed response compared to } \\
0 / 7 \text { p53 normal patients } \\
(P=0.017)\end{array}$ & Nemunaitis et a $\left.\right|^{58,60}$ \\
\hline $\begin{array}{l}\text { Phase II: } 2 \times 10^{11} \text { particles } 2 \times / \text { d } \\
\text { for } 5 \text { consecutive days for } 2 \\
\text { consecutive weeks during a } 21 \text {-day } \\
\text { cycle }\end{array}$ & $10 / \mathrm{SCCHN}$ & Fever, injection site pain & $1 \mathrm{CR}, 4 \mathrm{SD}$ & $\begin{array}{l}\text { Increased fever, injection pain } \\
\text { compared to less frequent dosing }\end{array}$ & Nemunaitis et a $\left.\right|^{58,60}$ \\
\hline $\begin{array}{l}\text { Phase II: } 2 \times 10^{11} \text { particles } 1 \\
\text { injection for } 5 \text { consecutive days } \\
\text { every } 3 \text { weeks plus } \\
\text { Cisplatin/5FU }\end{array}$ & $37 / \mathrm{SCCHN}$ & $\begin{array}{l}\text { Fever, injection pain, expected } \\
\text { chemo-related toxicity }\end{array}$ & $\begin{array}{l}8 \mathrm{CR}, 11 \mathrm{PR} \text {, median survival } \\
10.5 \text { months }\end{array}$ & $\begin{array}{l}11 \text { patients w/more than one } \\
\text { lesion: } 9 / 11 \text { injected had a PR/CR } \\
\text { versus } 3 / 11 \mathrm{PR} / \mathrm{CR} \text { noninjected } \\
\text { lesions }\end{array}$ & Khuri et al ${ }^{61}$ \\
\hline $\begin{array}{l}\text { Phase I: intraperitumoral injection } \\
\text { up to } 2 \times 10^{12} \text { particles for } 5 \text { days } \\
\text { every } 3 \text { weeks }\end{array}$ & 16/ovarian cancer & $\begin{array}{l}\text { Flu-like symptoms, emesis, } \\
\text { abdominal pain. } 1 \text { grade III } \\
\text { abdominal pain and diarrhea }\end{array}$ & $0 \mathrm{PR} / \mathrm{CR}$ & $\begin{array}{l}\text { PCR positive for circulating virus } \\
15 \text { days after initial dose }\end{array}$ & Vasey et al ${ }^{62}$ \\
\hline $\begin{array}{l}\text { Phase I: } 2 \times 10^{11} \text { particles via i.v. } \\
\text { every week for } 6 \text { weeks and low- } \\
\text { dose IL-2 }\end{array}$ & 5/solid tumor & Fever & $0 \mathrm{PR} / \mathrm{CR}$ & $\begin{array}{l}\text { No enhancement in cytokine- } \\
\text { related toxicity }\end{array}$ & Nemunaitis et al ${ }^{63}$ \\
\hline $\begin{array}{l}\text { Phase I: } 2 \times 10^{12} \text { particles via i.v. } \\
\text { every week for } 6 \text { weeks+CPT11, } \\
\text { 5FU }\end{array}$ & $5 /$ colon cancer & Fever & $0 \mathrm{PR} / \mathrm{CR}$ & $\begin{array}{l}\text { Viral replication confirmed in } \\
\text { metastatic liver site } \\
\text { Day } 5\end{array}$ & Nemunaitis et al ${ }^{63}$ \\
\hline $\begin{array}{l}\text { I.v. infusion+i.t. injection } \\
\left(6 \times 10^{12} \mathrm{vp}\right)\end{array}$ & 5/hepatocellular cancer & $\begin{array}{l}\text { Grade I-II toxicity fever, no } \\
\text { significant increase in liver enzyme } \\
\text { levels }\end{array}$ & $1 \mathrm{PR}$ & & Habib et al ${ }^{64}$ \\
\hline $\begin{array}{l}\text { Phase I: } 2 \times 10^{8}-2 \times 10^{12} \mathrm{vp} \text { on } \\
\text { days } 1 \text { and } 8 \text { for two cycles. } \\
\text { Intrahepatic artery infusion in } \\
\text { combination w/5FU and leukovorin }\end{array}$ & $\begin{array}{l}9 / \text { colon cancer } 2 / \text { pancreatic } \\
\text { cancer }\end{array}$ & $\begin{array}{l}\text { Mild to moderate fever, rigors, and } \\
\text { fatigue. }\end{array}$ & $1 \mathrm{PR}\left(2 \times 10^{11} \mathrm{vp}\right)$ & $\begin{array}{l}\text { Viral replication detected } \\
>2 \times 10^{11} \mathrm{vp}\end{array}$ & Reid et $\mathrm{al}^{65}$ \\
\hline $\begin{array}{l}\text { Phase I: } 2 \times 10^{10}-2 \times 10^{13} \\
\text { particles i.v. every week for } 4 \\
\text { weeks+carboplatin and paclitaxel }\end{array}$ & 10/solid tumor & $\begin{array}{l}\text { Fever } \\
\text { Mild transaminitis } \\
\text { Transient increase in LFT at } \\
2 \times 10^{13} \text { particles }\end{array}$ & 0 PR/CR, 8 SD & $\begin{array}{l}\text { Confirmed viral replication at lung } \\
\text { metastatic (D5) site MTD } \\
\text { determined to be } 2 \times 10^{13} \text { particles } \\
2^{\circ} \text { LFT }\end{array}$ & Nemunaitis et al ${ }^{66}$ \\
\hline $\begin{array}{l}\text { Phase I: } 2 \times 10^{9}-2 \times 10^{12} \mathrm{vp} \text { via } \\
\text { CT-guided i.t. injection }\end{array}$ & 23/pancreatic cancer & Fever & 0 PR/CR, 6 MR, 10 SD & $\begin{array}{l}\text { Day } 22 \text { tumor biopsy — for viral } \\
\text { replication }\end{array}$ & Mulvihill et al ${ }^{67}$ \\
\hline $\begin{array}{l}\text { Phase II: } 2 \times 10^{12} \text { particles on days } \\
1 \text { and } 8 \text { through hepatic arterial } \\
\text { infusion } \\
\text { Starting on day } 22 \text { : combination w/ } \\
5 \text { FU and leukovorin every } 28 \text { days }\end{array}$ & $\begin{array}{l}\text { 27/gastrointestinal carcinoma } \\
\text { metastatic to the liver }\end{array}$ & $\begin{array}{l}\text { Reversible grade III/IV } \\
\text { hyperbilirubinemia in two patients; } \\
25 \text { fever ( } 3 \text { severe), } 20 \text { chills ( } 1 \text { life } \\
\text { threatening), } 13 \text { nausea ( } 1 \text { severe) }\end{array}$ & $3 \mathrm{PR}, 4 \mathrm{MR}, 9 \mathrm{SD}$ & & Reid et $\mathrm{al}^{68}$ \\
\hline $\begin{array}{l}\text { Phase I: eight injection EUS } \\
2 \times 10^{10}-2 \times 10^{11} \mathrm{vp} / \text { treatment }\end{array}$ & $21 /$ pancreas & $\begin{array}{l}\text { Mild transient flu-like symptoms, } 1 \\
\text { grade III fever }\end{array}$ & $2 \mathrm{PR}, 2 \mathrm{MR}, 6 \mathrm{SD}$ & & Hecht et al ${ }^{69}$ \\
\hline $\begin{array}{l}\text { Phase II: trial } 2 \times 10^{12} \text { vp q } 2 \text { week } \\
\text { via i.v., i.t. }\end{array}$ & 18/colon cancer & Flu like symptoms, nausea, emesis & $7 \mathrm{SD}$ & & Hamid et al ${ }^{70}$ \\
\hline $\begin{array}{l}\text { Phase II: unresectable i.t. injection } \\
6 \times 10^{9} \text { or } 1 \times 10^{10} \mathrm{PFU}\end{array}$ & 20/hepatabilliary & $\begin{array}{l}3 \text { hepatic toxicity, } 1 \text { anemia, } 1 \\
\text { infection, } 1 \text { arterial fibrillation }\end{array}$ & $1 \mathrm{PR}$ & $\begin{array}{l}8 \text { patients with } \geqslant 50 \% \text { decrease in } \\
\text { tumor markers }\end{array}$ & Makower et $\mathrm{al}^{71}$ \\
\hline
\end{tabular}

Another Onyx 015 trial: Hecht et al. ${ }^{69}$

A phase I/II trial of intratumoral endoscopic ultrasound injection of ONYX-015 with i.v. gemcitabine in unresectable pancreatic carcinoma.

Clin Cancer Res 2003;9:555-561. 
selective replication activity of Onyx 015 in malignant

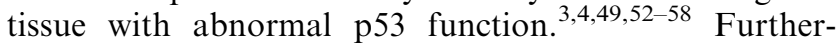
more, clinical tests of over 300 patients have shown no evidence of nonspecific viral replication or normal cell damage (Table 1, unpublished data) ${ }^{58-71}$ When administered intravenously (i.v.), dose escalation is limited by transient liver enzyme elevation at the $2 \times 10^{13}$ particle level. $^{66}$

To understand the specificity of Onyx 015 and other oncolytic adenoviruses, it is helpful to review the process of viral uptake and replication. The first encounter of the adenovirus with the target cell for most serotypes occurs through a high-affinity interaction of the adenovirus fiber protein with a cell surface receptor, the coxsackieadenovirus receptor (CAR), followed by low-affinity interaction between the adenovirus penton base protein and cell surface integrins. ${ }^{72-78}$ Receptor binding leads to internalization of the virus by the cell through receptormediated endocytosis, lysis of the endosomal membrane, escape to the cytosol, trafficking along microtubules towards the nucleus, binding the nuclear envelope, and insertion of the viral genome into the nucleus. ${ }^{79-88}$ The adenoviral reproductive cycle is a highly orchestrated process, and gene modification strategies, which enable selectivity, often reduce replication capacity. At the molecular level, completion of the infectious cycle relies on timely expression of a set of viral regulatory proteins that interact with essential endogenous cellular pathways that determine cell viability. ${ }^{89}$ The adenoviral genome contains eight transcriptional units that are activated at different phases of infection. They are referred to as early (E1A), immediate-early (E1B, E2, E3, E4), intermediate (IX and IVa2), and late genes. The early genes generate regulatory proteins that set the stage for viral DNA replication by blocking host cell antiviral mechanisms. $^{90,91} \mathrm{E} 1 \mathrm{~A}$ proteins are potent transactivators that provoke the infected cell to enter the cell cycle and progress to $\mathrm{S}$ phase. ${ }^{92}$ In $\mathrm{S}$ phase, the virus takes advantage of the cell's DNA replication machinery and replicates its $o w n$ genome. ${ }^{13}$ To prevent apoptosis due to unscheduled DNA synthesis, the adenovirus utilizes viral E1B-19K and E1B-55K proteins as part of the early gene activation phase. The E1B-55K protein, specifically, interferes with both p53-mediated apoptosis and p53's inhibition of cellular and viral replication by binding to $\mathrm{p} 53$. The virus inactivates p53 and $\mathrm{Rb}$ expressing viral E1B and E1A proteins, respectively. Mutants that fail to accomplish these functions because of deletions of the $\mathrm{E} 1 \mathrm{~B}^{2,13,93}$ or $\mathrm{E} 1 \mathrm{~A}^{6,8,12,94,95}$ regions selectively replicate within tumor cells that lack functional p53 or $\mathrm{Rb}$ function, respectively. Unfortunately, E1A and E1B genes have other roles in replication, so attenuation of these genes also reduces the mutant's replication ability compared to wild-type adenovirus. E1B-55K, for instance, facilitates transport of late viral mRNAs from the nucleus to the ribosomes. ${ }^{96}$ Impaired mRNA transport in the E1B-55K-deleted adenovirus is the probable cause of its reduced potency. ${ }^{52}$ The $\mathrm{E} 3$ region proteins maintain viral survival. ${ }^{97-102}$ Several E3-encoded gene products have been found that either block or activate cell death, and the coordinated and timely expression of these factors leads to optimal conditions for generating progeny. ${ }^{103}$ Adenoviruses lacking functional adenoviral death protein (ADP) located in the E3 region, for example, have been shown to induce host cell death and release progeny virus more slowly than wild-type adenovirus. ${ }^{104}$ Likewise, attenuated viruses with overexpressive ADP are more efficient at eradicating tumor cells than identical viruses lacking ADP. ${ }^{12}$ However, inappropriate timing of the expression of ADP may be counter productive depending on the therapeutic approaches being attempted. Viral constructs delivering prodrug inducible cytotoxins have been shown to be more effective when the cytotoxic gene is placed under late phase gene control. ${ }^{105}$ Deletion of ADP results in longer survival of virus in infected cells leading to an increased duration of ADP (or other late phase controlled expression transgenes). ${ }^{106}$ Other antiviral host defense mechanisms located on the E3 region include proteins that neutralize the effect of proinflammatory cytokine tumor necrosis factor (TNF). Adenoviruses containing deletions in many of these proteins have diminished replicative capacity or diminished ability to survive since they are less efficient at protecting the host cell from endogenous immune-mediated clearance. ${ }^{107}$ Nonreplicating viral vectors provide longer transgene expression in TNF knockout mice compared to wildtype mice. ${ }^{108,109}$ Furthermore, it has also been demonstrated that viral manufactured soluble binding proteins specific to TNF and other viral toxic cytokines such as interferon are also produced by other viruses including poxviruses, cytomegalovirus, herpesviruses, and adenoviruses. $^{91,110-115}$ Late viral genes encode structural proteins for the capsid and viral internal core. ${ }^{89}$ A great deal of preclinical work has been carried out utilizing modified capsid components to improve cancer targeting and reduce nontarget cell uptake.

Clinically, initial phase I investigation of Onyx 015 involved intratumor (i.t.) injection in refractory cancer patients. The virus was well tolerated and evidence of activity was suggested. ${ }^{116}$ Consequently, Onyx 015 was tested in a phase II study in patients with recurrent squamous cell cancer of the head and neck region (SCCHN). In one trial involving 40 patients injected i.t. with $2 \times 10^{11}$ viral particles for 5 consecutive days, cancerspecific viral replication was demonstrated in seven of 11 patients who underwent biopsy. No viral replication or toxic effect was identified in normal tissue. Interestingly, seven of 12 patients with p53 mutant cancers had responses, while zero of seven patients with cancer containing wild-type p53 genotype achieved a response. ${ }^{60}$ In a subsequent evaluation, 10 patients received a fourfold increase in dose but demonstrated no increase in response rate, although vector-related toxicity (fever, injection site pain) increased. ${ }^{60}$ Despite a relatively low response rate (nearly 20\%), safety was maintained (533 viral injections were administered), justifying further investigation in earlier stage chemotherapy naive recurrent SCCHN patients. In the next phase II study, patients received Onyx $015\left(2 \times 10^{11}\right.$ particles for 5 consecutive days $/ 21$ days $)$ in combination with cisplatin $\left(80 \mathrm{mg} / \mathrm{m}^{2}\right.$ 
once every 21 days) and 5-fluorouracil (5FU, 800$\left.1000 \mathrm{mg} / \mathrm{m}^{2} \mathrm{CI} \times 5 \mathrm{~d} / 21 \mathrm{~d}\right) .{ }^{61}$ The results were encouraging in that no added toxicity to Onyx 015 was demonstrated in addition to the expected toxicity of cisplatin and 5FU. Furthermore, a $63 \%$ response rate was observed, greater than the expected response rate of $35 \%$ from previous publications in the same patient population. ${ }^{61}$ Results of the SCCHN trials and other studies with Onyx 015 are summarized in Table 1.

Other clinical investigation of Onyx 015 utilizing intraperitoneal injection in advanced ovarian cancer ${ }^{62}$ revealed a similar toxicity as in $\mathrm{SCCHN},{ }^{59}$ although no responses were observed in ovarian cancer patients. Evidence of viral replication, however, was suggested based on continued detection of viral elements (via PCR) 15 days after the first injection. Other trials include patients with hepatocellular carcinoma. In one small pilot trial, one out of five patients achieved a partial response (PR) following a combination of i.v. administration and i.t. injection of Onyx $015 .^{64}$ Two trials have been preformed in advanced pancreatic cancer patients using both CT-guided and ultrasound- (EUS) guided injection approaches. In the first involving 22 patients, six minor responses (MRs), but no PR or complete responses (CRs), were observed. ${ }^{67}$ Two PRs and two MRs were observed in the second trial with 21 patients. ${ }^{69}$ Two other trials involving colorectal cancer patients with liver metastasis receiving intrahepatic artery infusion of Onyx 015 demonstrated good tolerability and identified a small number of patient responses. ${ }^{68,65}$ In a meta-analysis ${ }^{65}$ summarizing the two intrahepatic arterial infusion trials, survival was compared between patients receiving less than $6 \times 10^{11}$ virus particles per infusion (seven patients) to those receiving greater than $6 \times 10^{11}$ virus particles per infusion (28 patients). A significant survival advantage was demonstrated in the high-dose group (359 days) over the low-dose group (155 days) (Fig 1). ${ }^{117}$

Onyx 015 has also been administered safely to more than 40 patients i.v. (Table 1). Results demonstrate a slightly higher frequency of febrile response than what is observed with i.t. administration of Onyx 015, although the frequency was similar to what was observed with intra-arterial infusion. At doses of less than $1 \times 10^{13}$ particles per infusion, no significant safety concerns were raised including situations in which virus was administered in combination with low-dose IL-2 or chemotherapy (paclitaxel, CPT11, and 5FU). The presence of Onyx 015

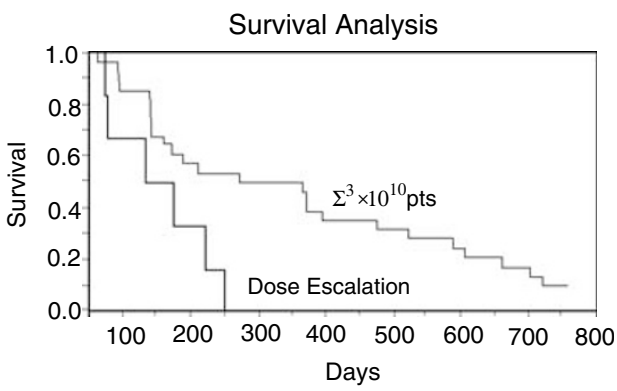

Figure 1 Survival of Onyx 015 by dose. within metastatic malignant disease sites following i.v. infusion was demonstrated; however, evidence of significant tumor regression was not. ${ }^{63,66,116}$

Future directions of clinical exploration with Onyx 015 are still being considered. Measures, which enhance Onyx 015 activity, are being explored and new generation adenoviruses are being developed. In conclusion, utilization of Onyx 015 via i.t. injection appears to be associated with modest activity, although clinical utility of local regional therapy is limited. Further exploration via intrahepatic arterial infusion or i.v. infusion awaits discovery of methods to improve Onyx 015 target specificity and activity.

\section{Enhancement of oncolytic viral therapeutic potency}

Therapeutic limitations to the efficient and selective use of replication-conditional adenoviruses as a systemic therapeutics include clearance, target cell specificity, uptake, replication rate, and oncolytic potency. Natural immune mechanisms are responsible for the clearance of viral particles and attempts to modulate viral clearance are currently being studied. Some measures suggest activity, including those that modulate neutralizing antibodies such as plasma apheresis, B-cell function inhibitors, immune suppressive therapy, and/or desensitization. ${ }^{118-134}$ Combination therapy with other anticancer agents that may also affect the activity of conditional replicating adenoviruses is also being explored. For instance, it has been demonstrated that adenoviral binding is optimal during the $\mathrm{M}$ phase of the cell cycle. Paclitaxel stabilizes microtubules that halts the cell cycle at $M$ phase and increases adenoviral binding and transgene expression. ${ }^{135,136}$ Agents such as paclitaxel, vinblastine, and docetaxel may potentially contribute to increased efficacy when combined with adenoviral therapies. $^{137-139}$

Immune response against infected tumor cells also appears to limit virus propagation via premature killing of the infected cells. This is a problem with oncolytic herpes simplex virus (HSV) ${ }^{140}$ and likely affects the persistence of adenovirus.

Targeting is a critical issue in the effective use of oncolytic viruses as systemic therapeutics. Tumor antigens on the cell surface expressed in high concentration may be utilized to facilitate viral targeting to malignant tissue. CAR expression, for instance, is variable in human cancer. ${ }^{141-154}$ In fact, there is some suggestion that CAR expression is downmodulated in advanced cancers. ${ }^{155,156}$ Retargeting to receptors other than CAR allows oncolytic viruses to bind to alternative cellular receptors resulting in "CAR-independent infection". Targeting complexes have already been developed to bind to receptors for folate, ${ }^{157}$ EGF, ${ }^{142,158-161}$ EpCAM, ${ }^{162}$ and FGF2. ${ }^{163-165}$ Activity has also been described in preclinical trials using an antifiber-Fab FGF2 retargeting molecule that links adenovirus components to the FGF2 receptor on the malignant cell. ${ }^{164-168}$ In some cases, retargeting has been shown to be more efficient than the native adenovirus pathway. ${ }^{169}$ Retargeting with specificity to malignant 
tissue may enable viruses to be administered at higher doses with reduced toxicity. ${ }^{166,167}$ In addition, CAR surface expression is strongly expressed on normal cells, which may allow it to serve as a sink and bind the therapeutic dose, limiting viral exposure to malignant tissue. For example, Kupffer cells in the liver are highly active in clearing viral particles. ${ }^{170,171}$ Transient inhibition of viral uptake by Kupffer cells has been shown to improve uptake beyond the liver following i.v. administration of adenoviruses. ${ }^{170}$ Several studies attempting to uncouple the adenovirus from its normal cellular receptor (CAR) and retarget tumor cell surfaces with single chain antibodies, growth vectors, or peptides are ongoing. ${ }^{172} \mathrm{~A}$ mutant measles virus in fact has already had its natural cellular receptor modified to target-specific tumor cell antigens. ${ }^{173-175}$ Another strategy for facilitating selectivity of oncolytic viruses is "intracellular targeting." Cancer cells, for instance, generally lack an interferon response, which is toxic to infecting viral organisms in normal cells. Oncolytic viruses dependent on interferon for clearance (vesicular stomatitis virus, Newcastle virus, myxoma virus, PV701) have significant growth advantage in these cancer cells. ${ }^{176}$ Likewise, reovirus growth has shown a selectivity to cells with an activated ras signaling pathway presumably through the downregulation of interferoninduced expression of PKR. ${ }^{1}$ Intracellular targeting can also be facilitated by transcriptionally programming viruses to replicate within malignant tissue by substituting viral promoters with cellular promoter elements. ${ }^{177-183}$ For example, poliovirus has been detargeted from nondividing neuronal cells and retargeted to replicate in malignant glioma cells by exchanging internal ribosomal entry site (IRES) elements from rhinovirus to polio. ${ }^{184}$ The combination of a $3^{\prime}$ polio UTR sequence with a $5^{\prime}$ rhinovirus IRES element creates a chimeric virus that is incapable of efficient translation in neuronal cells, but is well translated in malignant cells. ${ }^{1}$ Other studies have explored cancer and/or tissue-specific promoters that selectively control the cell site of viral replication (Table 2). Adenoviral replication can be restricted to specific cancers and tissues by placing transcriptional elements only responsive to those cancers in the early region of the viral genome. These DNA sequences, or promoters, prevent viral replication unless the infected cell produces the protein encoded for the DNA sequence. The demonstration that injections of CV706 could destroy large PSA-producing tumors in xenograft models supported translation to clinical trials.

\section{Promoter-driven viral therapeutics}

One, the PSA promoter, is already being utilized in clinical trial. The CV706 replication-competent adenovirus, formerly known as CN706, contains a genetically modified E1A gene controlled by a PSA promoter region. Preclinical in vitro studies confirm increased viral replication in PSA-producing cells when compared to non-PSAproducing prostate cancer cells. ${ }^{197}$ Furthermore, single injections of CV706 destroyed large PSA-producing tumors in mouse xenograft models, leading to clinical trials. ${ }^{197}$ These initial phase I trials confirmed replication specificity and suggested efficacy (Table 3 ). In one study, 20 men with locally recurrent prostate cancer after failing radiation therapy received single injections of CV706 ranging from $1 \times 10^{11}$ to $1 \times 10^{13}$ viral particles through a transrectal ultrasound-guided transperitoneal technique. $^{185}$ PCR analysis confirmed the shedding of viral DNA in the blood, suggesting replication. ${ }^{185}$ A total of 13 patients experienced more than a $30 \%$ decrease in PSA levels, and all five patients given the two highest doses had more than a $50 \%$ decrease in PSA, suggesting efficacy. ${ }^{185}$ The majority $(74 \%)$ of adverse events were grade I, and the most common low-grade adverse events (grade II and below) were low-grade fever, injection site pain, and hematuria. $^{185}$ Five serious events (grade III or higher) were recorded, but they were reversible and not related to

Table 2 Summary of inducible cancer promoters linked to viral replication

\begin{tabular}{|c|c|c|}
\hline Promoter & Targeted cancer & Reference \\
\hline PSA & Prostate cancer & DeWeese et $\mathrm{al}^{185}$ \\
\hline$\alpha$-fetoprotein & Hepatocellular cancer & Hallenbeck et al ${ }^{186}$ \\
\hline MMTV & Breast cancer & Lee et $\mathrm{al}^{187}$ \\
\hline $\begin{array}{l}\text { MDR1 (not to a specific cancer but to human drug } \\
\text { resistance gene inducible by cytostatic drugs) }\end{array}$ & & Walther et al ${ }^{188}$ \\
\hline TYR (tyrosinase) & Melanoma & Vile and Hart ${ }^{189}$ \\
\hline Neuronal specific & CNS malignancies & Morelli et al ${ }^{190}$ \\
\hline CEA & Colon cancer & Gao et $\mathrm{al}^{191}$ \\
\hline $\mathrm{MUCl}$ & Breast & Kurihara et $\mathrm{al}^{9}$ \\
\hline pS2 & Breast & Hernandez-Alcoceba et al ${ }^{192}$ \\
\hline HPV16 and HPV18 & SCCHN, cervix & Steele et $\mathrm{al}^{193}$ \\
\hline Rous sarcoma virus & $\mathrm{SCCHN}$ & Thompson et $\mathrm{al}^{194}$ \\
\hline Keratin gene & $\mathrm{SCCHN}$ & Gibson et al ${ }^{195}$ \\
\hline FLK1 & Endothelial cells/solid tumor & Savontaus et al ${ }^{183}$ \\
\hline hTERT & Solid tumor/telomerase & Kim et al $^{196}$ \\
\hline Kallikrein & Prostate cancer & Rodriguez et $\mathrm{al}^{197}$ and $\mathrm{Yu}$ et $\mathrm{al}^{4}$ \\
\hline EF1alpha & Solid tumor & Thompson et $\mathrm{al}^{194}$ \\
\hline P5 & Solid tumor & Kawakami et al ${ }^{198}$ \\
\hline
\end{tabular}


648

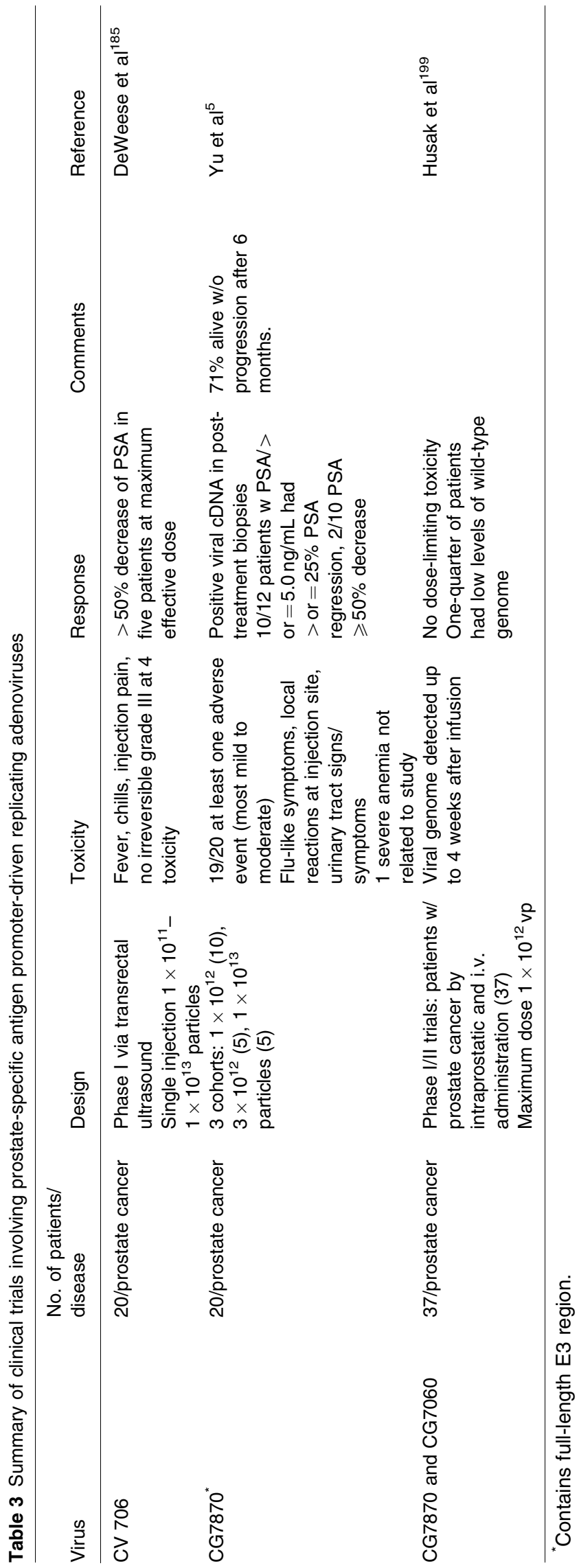

CV706. ${ }^{185}$ This trial confirmed safety and provided support for additional clinical testing and for the development of prostate-specific adenoviral vectors.

Another prostate-specific replication-competent adenovirus is CG7870. CG7870 has improved replication specificity over an older generation PSA-specific virus CV706, because both its E1A and E1B genes are under the control of prostate-specific transcriptional regulatory elements. ${ }^{5}$ In one preclinical trial, nude mice with PSApositive prostate cancer xenografts were injected with CG7870 through the tail vein. Results indicated a 100fold increase in efficacy over CV706. In addition, CG7870 effected significant responses in distant tumor sites, suggesting efficacy in administering the virus i.v. ${ }^{5}$ In a phase I/II trial, CG7870 was administered through intraprostatic injection to 20 patients with locally recurrent hormone naive prostate cancer with doses from $1 \times 10^{12}$ to $1 \times 10^{13}$ particles. In eight of 12 evaluable patients (including three of three at the highest dose level), PSA levels decreased by $25-50 \%$. In addition, $75 \%$ of evaluable patients remained progression free after 6 months. No serious adverse events from CG7870 resulted from the study. Only one grade III toxic event occurred, an elevated d-dimer and it resolved without treatment within 29 days. ${ }^{200}$ In a follow-up of several trials with both CG7870 and CV706, all 37 patients studied had various levels of circulating viral genome for up to 4 weeks after treatment. No dose-limiting toxicities were encountered, indicating that the virus was well tolerated at doses of up to $10^{13}$ particles. ${ }^{199}$ Future therapeutics are currently exploring transgene delivery using the CG7870 backbone with Diphtheria toxin A. ${ }^{201,202}$

Other selective transcriptional promoters currently being tested (Table 2) include: PSA and kallikrein for prostate cancer, ${ }^{5,197,185} \alpha$-fetoprotein for hepatocellular cancer, ${ }^{186}$ TYR promoter for melanoma, ${ }^{189}$ and carcinoembryonic antigen (CEA) for colon cancer. ${ }^{191}$ The MMTV ${ }^{187}{ }^{10 U C I},{ }^{9}$ and $\mathrm{pS} 2$ promoters ${ }^{192}$ are also being tested for breast cancer as are a number of promoters for head and neck cancer including HPV 16 and HPV $18^{193}$ and Rous sarcoma virus. ${ }^{194}$ FLK1 promoter is being tested for endothelial cells and other solid tumors, ${ }^{183}$ and hTERT, a telomerase promoter, is being tested in solid tumors. ${ }^{196}$ Tissue-specific promoters help adenoviruses concentrate replication in specific tissues, aiding in selective replication, and provide an additional safety mechanism to prevent replication in normal cells. This technology is especially useful in systemic administration of adenoviruses, as it should prevent replication in cells not containing such molecular abnormalities (normal cells). Other promoters, which have not been tested extensively in animal trials, include a promoter for Rous sarcoma virus, ${ }^{194}$ EF1alpha promoter, ${ }^{194}$ promoters for keratin genes, ${ }^{194,188,203}$ and the $\mathrm{p} 5$ promoter of the AAV. ${ }^{198}$

Newcastle virus. Newcastle virus is a paramyxovirus with infectivity normally restricted to fowl. It is an enveloped negative-stranded RNA virus, which selectively replicates in human cancer cells with defects in 
the interferon signaling pathway. ${ }^{204}$ Most early studies used Newcastle virus as an oncolysate tumor vaccine. These vaccines would then be injected into patients to generate an immune response. ${ }^{176}$ Clinical trials involving Newcastle disease virus are summarized in Table 4. In addition, the virus has been given i.v., intraperitoneally, and i.t. in athymic mice implanted with human cancers. These preclinical trials have shown few systemic side effects, and have demonstrated evidence of activity. ${ }^{134,216-218}$

The first report of activity with Newcastle virus involved one patient with cervical cancer. Cassel and Garrett $^{208}$ injected virus $\left(2.4 \times 10^{12}\right.$ virus particles $)$ directly into the tumor and demonstrated intratumoral regression of the cancer both at the injection site and at a distant malignant lymph node. In a phase II study in 1975, allogeneic and autologous human melanoma cells infected with Newcastle virus were used as an oncolysate postoperatively for patients with stage III melanoma. In addition to an increased number of $\mathrm{CD} 8^{+} \mathrm{T}$ cells, a 15 year follow-up indicated a $55 \%$ rate of survival. ${ }^{207,206}$ In another trial involving patients with high-risk stage II melanoma, viral oncolysate was administered following surgical excision of metastatic nodes (virus was administered weekly to week 4 , then biweekly to week 52 , then every 6 weeks to week 160). After 3 years of treatment, progressive disease occurred in only $12 \%$ of patients. Also, for 83 patients, survival was $68 \%$ after 5 years, significantly higher than historical controls. ${ }^{209,210,212}$ Autologous NDV oncolysate was also used in a phase II trial to treat colorectal cancer after the resection of metastatic liver lesions. ${ }^{213}$ The oncolysate was initiated 2 weeks after surgery and administered every 2 weeks for five cycles with one booster 3 months later. Nine of 23 patients had in increase in delayed-type hypersensitivity reactions when irradiated autologous tumor cells were placed intradermally after treatment. Of the patients, $61 \%$ developed recurrent disease, lower than the $87 \%$ recurrence in historical controls. Toxicity was limited in both this trial and the melanoma trial with side effects restricted to local inflammation and mild fevers. ${ }^{213}$ Newcastle virus has also been used as a surgical adjuvant vaccine in 208 patients with locally advanced renal cancer. In addition to oncolysate, these patients also received lowdose interferon-alpha and IL-2. The median disease-free survival was $21+$ months, higher than similar historical controls, while toxicity was limited to fever, flu-like symptoms, and local inflammation. ${ }^{214}$ In another trial, oncolysate was administered on days 1, 7, and 42 to 63 patients with primary breast cancer, 27 patients with recurrent breast cancer, and 31 patients with metastatic ovarian cancer. In addition, they all received low-dose IL$2\left(1 \times 10^{6}\right.$ IU subcutaneously on days $1-19$ and 42 to 60$)$ and interferon-alpha $\left(3 \times 10^{6} \mathrm{IU}\right.$ subcutaneously 3 days a week). Although patients with primary breast cancer had a survival benefit compared to historical controls, the other groups had no suggestion of survival advantage. ${ }^{215}$

Newcastle virus has also been tested via i.v. infusion and has been well tolerated. In one placebo-controlled phase II study, 33 patients with advanced cancer received virus and 26 control patients were given placebo treatment (Table 2). Of the patients treated with virus, seven patients achieved a complete or PR and one patient had a MR: these eight patients survived more than 1 year after treatment. In comparison, none of the control patients had responses. A total of 22 patients receiving virus survived longer than 1 year, whereas only four patients in the control group survived 1 year. Eight viral treated patients survived for more than 2 years, whereas none of the control patients survived that long. ${ }^{39}$

Most recently, a phase I trial of an attenuated Newcastle virus strain, PV701, was administered i.v. $\left(5.9 \times 10^{9} \mathrm{PFU} / \mathrm{m}^{2}\right.$ to $24 \times 10^{9} \mathrm{PFU} / \mathrm{m}^{2}$ every 28 days $)$ in 79 patients with solid tumors (Table 4 ). Side effects were mild and were limited to fever, flu-like symptoms, and hypotension. Seven grade III adverse events were observed, but toxicity decreased with subsequent doses. A maximum-tolerated dose (MTD) following a single infusion was established at $12 \times 10^{9} \mathrm{PFU} / \mathrm{m}^{2}$, and subsequent infusions were tolerated up to $120 \times 10^{9} \mathrm{PFU} / \mathrm{m}^{2}$. Further dose escalation was limited by patients developing hypotension. Of 62 patients, 14 eligible for response assessment maintained stable disease (SD) for 4 months to more than 30 months. One patient with squamous cell cancer on his tonsil achieved a CR. Another patient with metastatic colon cancer achieved a PR. Seven patients achieved MRs of less than a 50\% reduction in tumor size. The presence of viral particles was confirmed in malignant tissue following treatment.

In conclusion, Newcastle disease virus approaches have demonstrated an acceptable toxicity profile. The most recent construct, PV701, has been well tolerated via i.v. infusion and warrants further investigation.

Herpes simplex virus. $\mathrm{HSV}$ is a double-stranded DNA virus. Initial genetic modification used to construct oncolytic forms of this virus enabled selective activity within malignant tissue. One modification involved inactivation of viral gene ICP6 that encodes the large subunit of ribonucleotide reductase, an enzyme required for viral DNA replication. ${ }^{219-222}$ This enzyme is expressed abundantly in rapidly dividing tumor cells, but is more sparse in normal cells. As a consequence, the ICP6 gene modified HSV-1 replicates selectively in tumor cells. The second approach consists of deleting another viral gene (the $\gamma-34.5$ gene), which functions as the virulence factor during HSV infection. ${ }^{223}$ Mutations in this gene also limit replication in nondividing cells. ${ }^{224,225}$ The oncolytic HSV1 virus, G207, has been extensively tested in animal models and is currently in clinical trials. ${ }^{226-229}$ Replication-sensitive HSV1 $\gamma-34.5$ viral mutants have been shown to be effective in treating both $\mathrm{CNS}^{230-232}$ and non$\mathrm{CNS}^{233-241}$ tumors in animal models. Clinical trials involving patients with high-grade glioma, colorectal cancer, solid tumors, and melanoma ${ }^{242-245}$ have demonstrated safety. Results are summarized in Table 5. Four different herpes simplex oncolytic viruses have been tested in clinical trial (Table 6). Toxicity in the form of fever, chills, and transient liver enzyme elevation has been found to be greater in patients who have low initial HSV-1 
Table 4 Clinical trials involving Newcastle disease virus

\begin{tabular}{|c|c|c|c|}
\hline Trial/design (\# patients) & Efficacy & Side effects & References \\
\hline Phase I: solid tumor (80) & $14 / 62$ stable disease $\geqslant 4$ months & MTD $120 \times 10^{9} \mathrm{PFU} / \mathrm{m}^{2}$ & Pecora et al ${ }^{205}$ \\
\hline Given via i.v. infusion & $\begin{array}{l}1 \mathrm{CR}-\text { squamous cell cancer of the tonsil } \\
1 \mathrm{PR}-\text { colon cancer }\end{array}$ & $\begin{array}{l}\text { Mild: flu-like symptoms, mild } \\
\text { hypotension }\end{array}$ & \\
\hline $\begin{array}{l}\text { Phase II: stage III melanoma } \\
\text { Oncolysate consisting of allogeneic and autologous } \\
\text { human melanoma cells infected w/live Newcastle } \\
\text { virus - administered postoperatively }\end{array}$ & $\begin{array}{l}\text { Evidence of increased number of CD } 8^{+} \mathrm{T} \text { cells } \\
15 \text {-year follow-up showed } 55 \% \text { overall survival }\end{array}$ & Transient fever & $\begin{array}{l}\text { Schirrmacher et } \mathrm{al}^{206} \text { Batliwalla } \\
\text { et } \mathrm{al}^{207}\end{array}$ \\
\hline $\begin{array}{l}\text { Case report: direct injection, cancer of the cervix } \\
\text { (one patient) }\end{array}$ & $\begin{array}{l}\text { I.t. regression of the cancer at the site of the } \\
\text { injection and also regression of a distant malignant } \\
\text { lymph node } \\
\text { Detection of replicating virus w/in urine } 11 \text { days } \\
\text { after injection }\end{array}$ & Transient fever & Cassel $^{208}$ \\
\hline $\begin{array}{l}\text { Phase II: advanced cancer ( } 33 \text { patients) (versus } \\
\text { control of } 26 \text { placebo inhalants) }\end{array}$ & $\begin{array}{l}7 \mathrm{CR} / \mathrm{PR} \\
1 \mathrm{MR} \\
\text { No responses in control patients } \\
22 / 33 \text { survived at least } 1 \text { year versus } 4 / 26 \text { control } \\
\text { patients } \\
7 \text { at least } 2 \text { years versus none control } 7 / 8 \mathrm{w} / \\
\text { colorectal cancer metastatic to the liver survived } 1 \\
\text { year versus } 1 / 5 \text { control. }\end{array}$ & Transient fever & Csatary et $\mathrm{al}^{39}$ \\
\hline $\begin{array}{l}\text { High-risk stage II melanoma ( } 83 \text { patients) tested } \\
\text { after surgical excision of metastatic nodes. } \\
\text { Viral oncolysate administered weekly to week } 4 \text {, } \\
\text { then every } 2 \text { weeks to week } 52 \text {, then every } 3 \text { weeks } \\
\text { to week } 120 \text {, then every } 6 \text { weeks to week } 160 \text {. }\end{array}$ & $\begin{array}{l}\text { Evidence of progressive disease } 6 \% \text { at } 1 \text { year, } 8 \% \\
\text { at } 2 \text { years, } 12 \% \text { at } 3 \text { years } 88 \% \text { of } 83 \text { patients } \\
\text { survived } 3 \text { years and } 68 \% \text { survived } 5 \text { years. }\end{array}$ & Fever, local pain & $\begin{array}{l}\text { Cassel et al }{ }^{209} \text {, Cassel and } \\
\text { Murray }^{210,211} \text { and Sinkovics and } \\
\text { Horvath }^{212}\end{array}$ \\
\hline $\begin{array}{l}\text { Colorectal cancer following resection of metastatic } \\
\text { liver lesions ( } 23 \text { patients) } \\
\text { Autologous NDV oncolysate used: initiated } 2 \text { weeks } \\
\text { after surgery and repeated five times at } 2 \text {-week } \\
\text { intervals followed by one boost } 3 \text { months later }\end{array}$ & $\begin{array}{l}9 / 23(40 \%) \text { increase in delayed-type } \\
\text { hypersensitivity reactions to irradiated autologous } \\
\text { tumor cells placed intradermally after vaccination } \\
61 \% \text { of patients had disease recur w/in } 18 \text { months } \\
\text { versus } 87 \% \text { recurrence in } 130 \text { control patients who } \\
\text { underwent the same surgical procedure. }\end{array}$ & Fever, local pain & Schlag et $\mathrm{al}^{213}$ \\
\hline $\begin{array}{l}\text { Locally advanced renal cell carcinoma (208) } \\
\text { Surgical adjuvant vaccine: low-dose IL-2 and } \\
\text { interferon-alpha in combination w/the oncolysate. }\end{array}$ & Median disease-free survival was $21+$ months & $\begin{array}{l}\text { Low-grade fever, mild flu-like } \\
\text { symptoms, local inflammation }\end{array}$ & Kirschner et $\mathrm{al}^{214}$ \\
\hline $\begin{array}{l}\text { Primary breast cancer (63), recurrent breast cancer } \\
\text { (27), and metastatic ovarian cancer ( } 31) \text {. } \\
\text { Administered on days } 1,7 \text {, and } 42 \\
\text { Also received low-dose IL-2 }\left(1 \times 10^{6} \mathrm{IU} \text { daily }\right. \\
\text { subcutaneously) on days } 1-19 \text { and } 42-60 \\
\text { Also received interferon-alpha }\left(3 \times 10^{6} \mathrm{IU}\right. \\
\text { subcutaneously } 3 \text { days per week) for the first } 18 \\
\text { days, then } 3 \text { days per week between days } 42 \text { and } \\
58\end{array}$ & $\begin{array}{l}\text { Primary breast cancer patients appeared to have a } \\
\text { survival benefit compared to historical controls, but } \\
\text { no survival advantage suggested in the other } \\
\text { disease groups }\end{array}$ & & Haas et $\mathrm{al}^{215}$ \\
\hline
\end{tabular}
used: initiated 2 weeks after surgery and repeated five times at 2-week

Locally advanced renal cell carcinoma (208) Surgical adjuvant vaccine: low-dose IL-2 and interferon-alpha in combination $\mathrm{w} /$ the oncolysate. 
Table 5 Summary of clinical trials with HSV

\begin{tabular}{|c|c|c|c|c|c|}
\hline Specific virus & Trial/design & Efficacy & Side effects & References & Comments \\
\hline NV1020 & $\begin{array}{l}\text { Phase I study in patients (12) } \\
\text { w/adenocarcinoma of the } \\
\text { colon w/metastasis to the liver } \\
\text { Single intrahepatic arterial } \\
\text { infusion (doses from } 3 \times 10^{6} \text { to } \\
1 \times 10^{8} \mathrm{PFU} \text { ) On day } 28 \text { and } 1 \\
\text { month later, all patients } \\
\text { received chemo of either } 5 \mathrm{FU} \\
\text { (via pump) or CPT11 (via i.v.) }\end{array}$ & $\begin{array}{l}\text { Decreases in tumor size noted } \\
\text { for } 2 \text { patients up to } 28 \text { days } \\
\text { after NV } 1020 \text { administration } \\
1 \text { (at } 3 \times 10^{7} \mathrm{PFU} \text { ) showed } \\
\text { overall reduction of at least } \\
20 \% \text { in tumor measurements } \\
\text { at } 28 \text { days (prior to receiving } \\
\text { chemo). By month } 2 \text {, it further } \\
\text { regressed to a PR of at least } \\
50 \% \\
\text { Second patient treated w/ } \\
1 \times 10^{8} \mathrm{PFU} \text { similar PR by } \\
\text { month } 2 \text {. Both PRs observed } \\
\text { after the initiation of chemo w/ } \\
5 \mathrm{FU} \text { and CPT } 11 \\
4 \text { other patients MRs w/at least } \\
25 \% \text { reduction in tumor size } \\
\text { after chemo. }\end{array}$ & $\begin{array}{l}\text { Pain }(75 \%) \text {, pyrexia }(58 \%) \text {, } \\
\text { headache }(50 \%) \\
\text { Tachycardia }(17 \%) \text {, nausea } \\
(17 \%) \text {, vomiting }(17 \%) \text {, rigors } \\
(25 \%) \\
\text { Transient elevation in gamma } \\
\text { glutamyl transferase, } \\
\text { gastroenteritis } \\
\text { No deaths } \\
\text { No dose-limiting toxicity } \\
\text { observed }\end{array}$ & Bennett et $\mathrm{al}^{246}$ & $\begin{array}{l}\text { 10/12 decrease in CEA } \\
\text { from baseline to day } 6 \\
\text { ( } 20 \% \text { below baseline). } \\
\text { Day } 14,7 / 12 \text { decrease. } \\
\text { After chemo, majority of } \\
\text { patients had at least } \\
50 \% \text { decline of CEA } \\
\text { levels. } \\
\text { No evidence of } \\
\text { disseminated HSV } \\
\text { infection, viral } \\
\text { reactivation, or } \\
\text { shedding } \\
\text { NV1020 detected in } \\
\text { one saliva sample and } \\
\text { two peripheral blood } \\
\text { samples from a single } \\
\text { patient treated at } \\
\text { highest dose level }\end{array}$ \\
\hline G207 & $\begin{array}{l}\text { Phase I: Recurrent glioma (21) } \\
\text { Intratumoral } \\
\text { Maximum dose: } 3 \times 10^{9} \mathrm{PFU} \\
\text { Minimum dose: } 1 \times 10^{6} \mathrm{PFU}\end{array}$ & $\begin{array}{l}\text { MRI volume decrease in eight } \\
\text { patients } \\
2 \text { patients alive over } 4 \text { years } \\
\text { G207 DNA detected by PCR in } \\
2 / 7 \text { patients }\end{array}$ & $\begin{array}{l}\text { Safety confirmed } \\
\text { No serious adverse events }\end{array}$ & Markert et $\mathrm{al}^{247}$ & \\
\hline HSV 1716 & $\begin{array}{l}\text { Phase I: Recurrent glioma (9) } \\
\text { Intratumoral } \\
\text { Maximum dose: } 1 \times 10^{5} \mathrm{PFU} \\
\text { Minimum dose: } 1 \times 10^{3} \mathrm{PFU}\end{array}$ & $\begin{array}{l}4 \text { patients alive over } 14 \\
\text { months }\end{array}$ & $\begin{array}{l}\text { Safety confirmed } \\
\text { No adverse events exhibited }\end{array}$ & Rampling et $\mathrm{al}^{248}$ & \\
\hline HSV 1716 & $\begin{array}{l}\text { Phase I: high-grade glioma } \\
(12)-\text { all but one patient } \\
\text { recurrent tumors. } \\
\text { I.t. injection } \\
\text { All } 1 \times 10^{5} \text { PFU } \\
\text { Tumor surgically resected } \\
\text { after } 4-9 \text { days }\end{array}$ & $\begin{array}{l}\text { Viral replication demonstrated } \\
\text { in two patients } \\
\text { Significant amounts of viral } \\
\text { DNA detected by PCR in } 10 \\
\text { patients }\end{array}$ & Safety confirmed & Papanastassiou et al ${ }^{249}$ & \\
\hline HSV 1716 & $\begin{array}{l}\text { Phase I: stage IV melanoma } \\
\text { (5) } \\
\text { Between } 1 \text { and } 4 \text { injections of } \\
1 \times 10^{3} \text { PFU into a single } \\
\text { nodule }\end{array}$ & $\begin{array}{l}\text { Histopathological evidence of } \\
\text { tumor necrosis in three } \\
\text { patients receiving multiple } \\
\text { injections. HSV antigen } \\
\text { detected by } \\
\text { immunohistochemistry only in } \\
\text { tumor cells. }\end{array}$ & & MacKie et $\mathrm{al}^{250}$ & \\
\hline Oncovex ${ }^{\mathrm{GM}-\mathrm{CSF}}$ & $\begin{array}{l}\text { Phase I: solid tumor (8) } 10^{6} \text {, } \\
10^{7} \mathrm{PFU} \text { direct injection }\end{array}$ & $\begin{array}{l}3 / 8 \text { detectable virus blood/ } \\
\text { urine }<2 \text { weeks } 1 \mathrm{PR}\end{array}$ & $\begin{array}{l}\text { Local tumor necrosis, pain, } \\
\text { fever }\end{array}$ & $\begin{array}{l}\text { Han et al, }{ }^{251} \text { Liu et al }{ }^{252} \\
\text { amd Hu et al }{ }^{253}\end{array}$ & Ongoing trial \\
\hline
\end{tabular}


Table 6 Herpesvirus constructs in clinical trial

\begin{tabular}{llll}
\hline Virus & Genes mutated & Transgenes & References \\
\hline NV 1020 & UL24, UL56, $\gamma 34.5$ & - & $222,244,254-256$ \\
G207 & ICP6, $\gamma 34.5$ & LAC 2 & $222,229,235,257$ \\
1716 & $\gamma 34.5$ & - & $222,224,234,258,259$ \\
Oncovex GM-CSF & $\gamma 34.5$, ICP47 & GM-CSF & 222,260 \\
\hline
\end{tabular}

Table 7 Summary of results with reovirus

\begin{tabular}{|c|c|c|c|c|}
\hline Reovirus (Reolysin) & $\begin{array}{l}\text { Phase I: i.t. injection solid tumor } \\
\text { (18) } 10^{7}-10^{10} \mathrm{PFU}\end{array}$ & $\begin{array}{l}\text { Serum PCR and for virus at } 10^{9} \text {, } \\
10^{10} \text { dose levels } \\
1 \mathrm{CR}, 1 \mathrm{PR}, 8 \mathrm{SD} \text { of injection } \\
\text { lesions }\end{array}$ & $\begin{array}{l}\text { Headache, transient flu-like } \\
\text { symptoms }\end{array}$ & Morris et $\mathrm{al}^{288}$ \\
\hline
\end{tabular}

antibody titers at baseline. However, all patients developed an immune antibody response against HSV antigens within weeks following treatment; thus, continued treatment to patients with high initial HSV antibody titers have had significantly less toxic effect. PCR analysis of tissue has revealed the presence of HSV DNA at injection sights. ${ }^{249}$ Preclinical results in immunecompetent models have also suggested immune-mediated distant responses, ${ }^{235,236,261-263}$ although a systemic immune effect has not yet been observed in clinical trial (Table 5). Given the significant lack of systemic activity of viral-induced oncolysis following local-regional treatment in the clinic, several new vectors carrying immunestimulating transgenes have been developed (GM-CSF, IL-2, IL-12, B7.1). ${ }^{263-268}$ In addition, combination of HSV mutants with chemotherapy or radiotherapy has demonstrated enhancement in antitumor activity. $^{222,243,269-274}$ Radiation enhanced anticancer activity of HSV when used in pancreatic, glioblastoma, and cervical cancer models, ${ }^{275}$ but did not alter the antitumor effect of HSV in prostate cancer. However, high-dose radiation combined with oncolytic $\mathrm{HSV}$ virus did improve efficacy in other prostate cancer models. ${ }^{244,271,272}$ Lowdose irradiation also improved efficacy of HSV viral therapy in a cervical cancer model. ${ }^{274}$ In chemotherapy combination studies, interestingly, both chemotherapyresistant and -sensitive tumors were equally responsive. ${ }^{276}$ A variety of chemotherapy agents (mitomycin C, cisplatin, methotrexate) have demonstrated enhancement in antitumor effect when combined with HSV. ${ }^{243}$

Other studies have also identified the use of HSV to deliver other genes, such as those that convert benign prodrugs into cytotoxic agents. In one particular study, cytochrome $P 450$ gene and HSV-1 thymidine kinase (TK) gene were delivered using a HSV-1 replication-competent virus via i.t. injection in a hepatocellular carcinoma model. ${ }^{277}$ Cancer regression significantly improved with the cytochrome $P 450$ conversion of cyclophosphamide to the active metabolite phosphoramide mustard. ${ }^{220}$ Similar results have been produced with cytosine deaminase transgene. $^{278}$ Interestingly, HSV TK metabolic activation of acyclovir or ganciclovir in HSV-infected cells inhibits viral replication without affecting tumor growth. ${ }^{237,279-281}$ This suggests that TK gene and ganciclovir may be useful as a safety valve if persistent virus and related toxicity developed. ${ }^{277}$

In conclusion, certain HSV vectors appear to be active and selective against malignant tissue. Safety, particularly with respect to neurovirulence, will require further clinical investigation at MTDs. Use of tissue promoters, such as albumin and calponin, ${ }^{282-284}$ as part of the viral core backbone combined with transgenes, which may potentiate systemic immune response (e.g. GM-CSF) may have promise for future therapeutics.

Reovirus: Reoviruses are double-stranded RNA viruses that cause mild respiratory and gastrointestinal illnesses in humans. Although normal mouse fibroblast cells (NIH3T3) do not normally support reovirus replication, NIH3T3 cells that have been transformed with activated ras, epidermal growth factor receptor, or V-erb B Oncogene (e.g. activated ras pathway elements) are lysed by uninhibited reovirus replication. It is now understood that an activated ras pathway (which is present in many ovarian, breast, colon, and lung cancers) prevents viralinduced PKR activation and subsequent EIF-2 alpha phosphorylation potentiating unabated cellular protein production and viral replication. As in normal cells without ras activation, early viral replication induces EIF2 alpha phosphorylation thereby inhibiting cell protein synthesis, reoviruses exhibit preferential oncolytic effects in ras activated cancer cells.

Reoviruses have demonstrated preclinical activity in mouse flank tumor models with cell lines that overexpress certain ras pathway elements. Examples include V-erbtransformed NIH3T3 cells, human V87 glioblastoma cells overexpressing platelet-derived growth factor receptor, and ras-transformed $\mathrm{C} 3 \mathrm{H}-10 \mathrm{~T} 1 / 2$ cells. $^{285}$ Reoviruses have also demonstrated activity against Lewis lung cancer metastasis in mice following i.v. administration. ${ }^{286}$ In this study, $65-80 \%$ of the mice tested showed regression in their tumors. ${ }^{286,287}$ Investigators have recently demonstrated oncolytic activity of reovirus against human ovarian and colon cancer cell lines carrying a high percentage of k-ras mutations implanted in mice. ${ }^{204}$ In 
addition to demonstrating the susceptibility of human colon and ovarian cancer cells to reovirus infection in vitro, this study assessed the ability of reovirus to cause tumor regression and promote survival in immunocompromised mice implanted with human colon and ovarian cancers. I.t. injection of virus consistently resulted in major reductions of the ovarian and colon cancer tumor volumes. Of particular significance, the i.v. administration of virus in the immunocompromised mice consistently resulted in the regression of tumors at a remote site.

In animal model studies and in human pathogenesis, reovirus has not caused severe or life-threatening symptoms. Accordingly, reovirus looks like a promising therapy for colon cancer, ovarian cancer, breast cancer, lung cancer, and other malignancies having activation of the ras pathway, especially as a systemic treatment in combination with immunosuppressive therapy. ${ }^{176}$ Clinically, 18 patients with refractory solid tumors have been treated in a phase I investigation, and a dose of up to $1 \times 10^{10}$ PFU has been well tolerated (Table 7). Preliminary results also identified one patient achieving a CR and 1 a PR. Eight maintained SD for a prolonged period. Further work is being developed.

Vaccinia: Vaccinia is a double-stranded DNA virus and a member of the poxvirus family. Vaccinia virus has tropism for human cells and its high immunogenicity. The immunogenicity properties were exploited in making smallpox vaccine that lead to the eradication of smallpox.

Three properties of vaccinia virus are being used to develop the virus as a cancer therapy. These include the following: (1) Vaccinia virus has a high efficiency of infection, it replicates in the cytoplasm without chromosomal integration, and the $200 \mathrm{~kb}$ genome allows the insertion of a large amount of recombinant DNA without losing infectivity. (2) To develop cancer vaccines, the immunostimulatory properties of the virus are being harnessed to incite an immune response against cancer cells. (3) To develop an oncolytic virus, replicationconditional viral mutants are being constructed to target specific cancer types. We will briefly touch each of these areas.

The following are examples of preclinical and phase I trials (Table 8 ) that explore the use of vaccinia virus as a vector for gene therapy. In one study, ${ }^{299}$ recombinant vaccinia virus was constructed in an effort to enhance the immunogenicity of transfected melanoma cells. The virus expressed a minigene encoding a fusion product that combined an endoplasmic reticulum (ER) targeting signal and the HLA-A201 binding 27-35 peptide. Infection of melanoma cells with this recombinant virus resulted in high levels of cytotoxicity from activated specific CTL clones in vitro. ${ }^{300}$ In another study, ${ }^{300}$ a recombinant vaccinia virus vector was created containing the tumor suppressor 553 gene. This virus demonstrated a high level of expression of $\mathrm{p}-53$ protein in transfected glioma cells, resulting in high levels of apoptosis. ${ }^{289}$ A phase I study of intravesical vaccinia virus infection ${ }^{289}$ demonstrated that vaccinia virus can be safely administrated into the bladder and gave evidence that the treatment was associated with an intense immune response with few clinical side

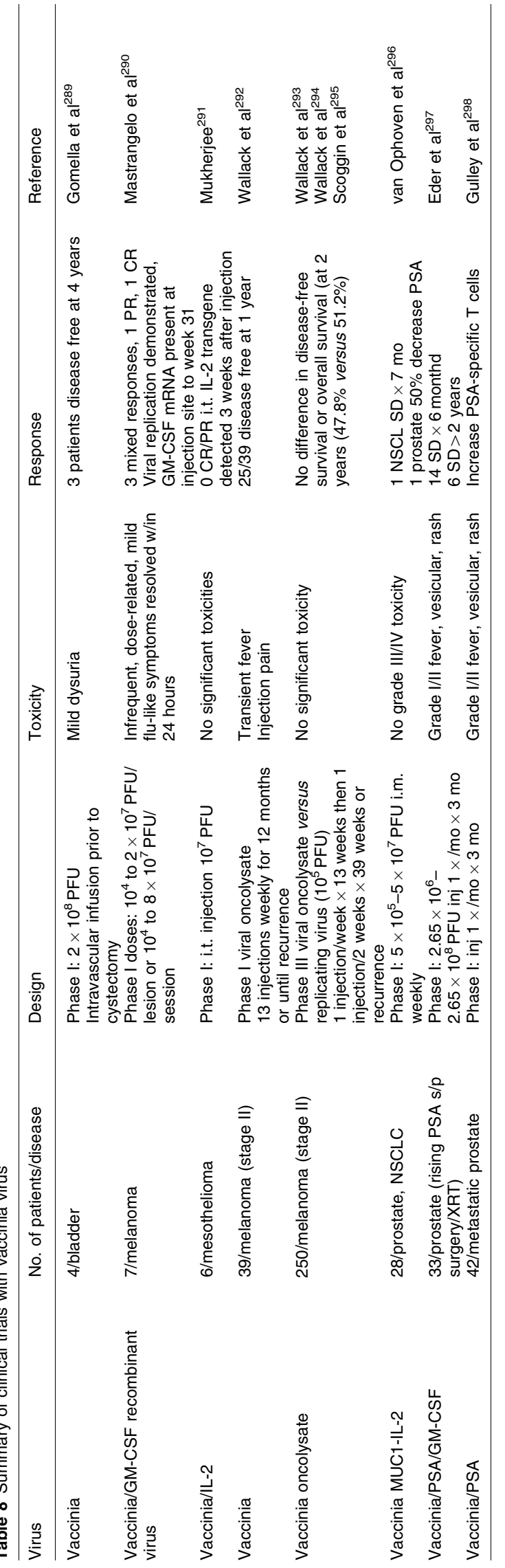


Table 9 Adenoviral gene delivery approach

\begin{tabular}{lllll}
\hline Specific virus & Trial/design & Efficacy & Side effects & References \\
\hline Ad5-CD/Tkrep & Phase I: 16 patients w/locally & $7 / 16$ had $\geqslant 25 \%$ decrease in PSA; & No dose-limiting toxicity $93 \%$ of & Freytag et al ${ }^{305}$ \\
& aggressive prostate cancer & $3 / 16 \geqslant 50 \%$ decrease PSA & adverse events grade I-II & Rogulski et al ${ }^{306}$ \\
& received single intraprostatic & Transgene expression confirmed & severity: no serious events \\
& injection $\left(10^{10}-10^{12}\right.$ particles) of & 2 weeks after injection. & & \\
& virus and then $1-3$ weeks of 5FC & & \\
& and vGCV and standard dose & & \\
& & & \\
3DCRT
\end{tabular}

effects. $^{294}$ Of the four patients studied, three of them survived and were free of disease at 4 years. The authors felt that the data supported further study of vaccinia virus vectors in the treatment of bladder cancer.

Many studies use vaccinia virus as an immunotherapeutic agent. Vaccinia oncolysate has been studied as a vaccine in early stage melanoma (Table 8). Results suggested good tolerability and survival advantage compared to historical controls. However, a prospective controlled trial failed to validate the use of vaccinia oncolysate. The control group did not receive standard care but, instead, it received live vaccinia virus without tumor oncolysate, which potentially could have affected patient response.

Wild-type vaccinia virus does not selectively infect cancer cells. The virus requires modification to be made replication conditional. One strategy is to delete the viral TK gene. While the viral TK gene is necessary for infectivity in normal cells that possess small concentrations of intracellular nucleotide pools, it is not necessary in cancer cells, ${ }^{290}$ which possess relatively high concentrations of intracellular nucleotides. Another novel vector involved replacing the viral TK gene with the gene for GM-CSF, creating a mutant vaccinia virus capable of selectively infecting melanoma cells, and inducing an antitumor immune response. ${ }^{290}$ This virus has been administered intralesionally in a phase I clinical trial involving patients with refractory and/or recurrent melanoma. Injected lesions contained an active inflammatory response and demonstrable viral replication. Two out of seven patients studied had a CR, and three patients had a PR. ${ }^{290}$ Other studies have also investigated a vaccinia virus carrying a PSA transgene in the treatment of both minimal disease and metastatic disease prostate cancer. Evidence of cancer-specific immune activation was demonstrated, and tolerability was reasonable. In minimal disease patients with rising PSA following surgery or radiation therapy, 14 of 33 maintained SD for at least 6 months and six remained disease free for greater than 2 years. Another mutant vaccinia virus, which deleted the viral SPI-1 and SPI-2 genes, resulted in conditional viral replication in cancer cells but not in normal cells. ${ }^{301}$ The efficacy of this virus has not yet been tested. Other gene combinations such as B7-1, ICAM-1, and LFA3 have also been added to the vaccinia core construct. Animal results are encouraging. ${ }^{302-304}$

In summary, whether using mutant vaccinia viruses having tumor selective replication features or using vaccinia virus tumor lysates as antitumor vaccines, vaccinia virus appears to offer multiple potentially effective ways to treat cancer.

\section{Other viral approaches}

A great deal has been learned with respect to use of replicating virus as a potential cancer therapeutic. Although activity has been demonstrated, FDA approvable products have not yet been generated. Clinical trials support the concept of selective and/or conditional oncolytic viral replication. Reported toxicities, even with wild-type adenovirus have not been clinically unacceptable with doses up to $10^{13}$ particles (adenovirus). In one study, ${ }^{240}$ an E1B-deleted adenovirus 5 containing a combined fusion gene of cytosine deaminase and $\mathrm{TK}^{7}$ was administered to 16 cancer patients (Table 9). ${ }^{305}$ There was no serious toxicity, although replication was inhibited early with the administration of 5FC and ganciclovir.

The E1B and E1A-deleted adenoviral vectors provide selective replication capacity and can be utilized as gene delivery vehicles to potentiate the viral oncolytic effect. ${ }^{307}$ Interestingly, in Freytag's work, ${ }^{7}$ the prodrug anticancer effect was greater than the direct viral cytolytic effect when the prodrug was administered early. Other viruses have also been explored preclinically as selective cancer therapeutics (e.g. Onyx $411,{ }^{307,308}$ poliovirus, ${ }^{309}$ vesicular stomatitis virus, ${ }^{310}$ influenza virus, ${ }^{311}$ and measles virus $^{312}$ ). Replicating bacteria have also been briefly tested in clinical trial. ${ }^{313}$ Additional measures to modify viral activity by combining treatment with relevant immune modulation therapy (rituximab, enbrel) requires further exploration. Other studies have also shown that modification of the E3 region may minimize viral potency with respect to the durability of selective replication. Modification of the E3 region appears to potentiate viral activity with respect to replication capacity, duration of survival, and induction of apoptosis. ${ }^{106,314,315}$ Changing the surface components, such as the fiber and knob, to alter cancer binding, particularly when CAR expression is reduced or not displayed has also demonstrated improved anticancer activity. ${ }^{316}$ Furthermore, contaminant of viral particles in liposomes or polymer-coated ligands may improve viral uptake particularly when administered systemically. ${ }^{317}$ 


\section{Conclusion}

Clinical instigation of conditional replicating oncolytic viral therapies continues to be pursued in oncology. There is a high degree of confidence now in the safety and selectivity of a variety of oncolytic viruses. Furthermore, understanding of viral biology has led to the modification of viral genome in order to address therapeutic options and safety issues. In addition, work now being carried out in addressing optimal viral surface coat components, systemic clearance factors, potency, replication capacity, oncolytic capacity, and gene delivery will begin to cross paths, as more is understood. This will lead to more potent treatments. For the future, we are heading towards developing selective replicating viruses that can avoid immune clearance, thereby enabling systemic administration. Ultimately, statistical confirmation of efficacy will need to be demonstrated in comparison to standard of care measures. One day cancer may be targeted for treatment based on specific molecular abnormalities rather than histologic characterization, and the therapeutic effect of such selective replicating viruses will be limited to the cancer and not involve normal organs.

\section{Acknowledgments}

We would like to acknowledge Brenda Marr for her competent and knowledgeable assistance in the preparation of this manuscript.

\section{References}

1. Bell JC, Lichty B, Stojdl D. Getting oncolytic virus therapies off the ground. Cancer Cell. 2003;4:7-11.

2. Bischoff JR, Kirn DH, Williams A, et al. An adenovirus mutant that replicates selectively in p53-deficient human tumor cells. Science. 1996;274:373-376.

3. Heise C, Sampson-Johannes A, Williams A, McCormick F, Von Hoff DD, Kirn DH. ONYX-015, an E1B geneattenuated adenovirus, causes tumor-specific cytolysis and antitumoral efficacy that can be augmented by standard chemotherapeutic agents. Nat Med. 1997;3:639-645.

4. Yu DC, Sakamoto GT, Henderson DR. Identification of the transcriptional regulatory sequences of human kallikrein 2 and their use in the construction of calydon virus 764 , an attenuated replication competent adenovirus for prostate cancer therapy. Cancer Res. 1999;59:1498-1504.

5. Yu DC, Chen Y, Seng M, Dilley J, Henderson DR. The addition of adenovirus type 5 region E3 enables calydon virus 787 to eliminate distant prostate tumor xenografts. Cancer Res. 1999;59:4200-4203.

6. Heise C, Hermiston T, Johnson L, et al. An adenovirus E1A mutant that demonstrates potent and selective systemic anti-tumoral efficacy. Nat Med. 2000;6: $1134-1139$

7. Freytag SO, Rogulski KR, Paielli DL, Gilbert JD, Kim JH. A novel three-pronged approach to kill cancer cells selectively: concomitant viral, double suicide gene, and radiotherapy. Hum Gene Ther. 1998;9:1323-1333.
8. Fueyo J, Gomez-Manzano C, Alemany R, et al. A mutant oncolytic adenovirus targeting the $\mathrm{Rb}$ pathway produces anti-glioma effect in vivo. Oncogene. 2000;19:2-12.

9. Kurihara T, Brough DE, Kovesdi I, Kufe DW. Selectivity of a replication-competent adenovirus for human breast carcinoma cells expressing the $\mathrm{MUC1}$ antigen. $J$ Clin Invest. 2000;106:763-771.

10. Johnson L, et al. Cytosine deaminase-armed selectivelyreplicating adenovirus for the treatment of cancer. Proc Am Assoc Cancer Res. 2002;43:3257.

11. Hallenbeck PL, et al. Oncolytic adenoviruses dependent on two prevalent alterations in human cancer; disregulation of the Rb-pathway and telomerase. Mol Ther. 2002;5:165.

12. Doronin K, Toth K, Kuppuswamy M, et al. Tumorspecific, replication-competent adenovirus vectors overexpressing the adenovirus death protein. $J$ Virol. 2000;74:6147-6155.

13. Ramachandra M, Rahman A, Zou A, et al. Re-engineering adenovirus regulatory pathways to enhance oncolytic specificity and efficacy. Nat Biotechnol. 2001;19:1035-1041.

14. Hansen RM, Libnoch JA. Remission of chronic lymphocytic leukemia after smallpox vaccination. Arch Intern Med. 1978;138:1137-1138.

15. Bousser J, Zittoun R. Prolonged spontaneous remission of chronic lymphoid leukemia]. Nouv Rev Fr Hematol. 1965;5:498-501.

16. Vladimirskaia EB. A case of prolonged spontaneous remission in a patient with chronic lymphatic leukemia. Probl Gematol Pereliv Krovi. 1962;7:51-54.

17. Weintraub LR. Lymphosarcoma. JAMA. 1969;210: 1590-1591.

18. Sinkovics JG. Oncolytic viruses and viral oncolysates. Ann Immunol Hung. 1986;26:271-290.

19. Bluming AZ, Ziegler JL. Regression of Burkitt's lymphoma in association with measles infection. Lancet. 1971;2: $105-106$

20. Taqi AM, Abdurrahman MB, Yakubu AM, Fleming AF. Regression of Hodgkin's disease after measles. Lancet. 1981;1:1112.

21. Bierman HR, Crile DM, Dod KS, et al. Remissions in leukemia of childhood following acute infectious disease: staphylococcus and streptococcus, varicella, and feline panleukopenia. Cancer. 1953;6:591-605.

22. Pelner L, Fowler GA, Nauts HC. Effects of concurrent infections and their toxins on the course of leukemia. Acta Med Scand. 1958;162:1-47.

23. London RE. Multiple myeloma: report of a case showing unusual remission lasting two years following severe hepatitis. Ann Intern Med. 1955;43:191-201.

24. Dock G. Influence of complicating diseases upon leukemia. Am J Med Sci. 1904;127:563-592.

25. Bierman HR, Hammon W, Eddie BU, Meyer KF, Shimkin MB. The effect of viruses and bacterial infections on neoplastic diseases. Can Res. 1950;10:203-204.

26. Hernandez A. Observacion de un case de enfermedad de Hodgkin, con regresion de los sintomas e infartos ganglionares, post-sarampion. Rev Med Cubana. 1949;60:120-125.

27. De Pace NG. Sulla scomparsa di un enorme cancro vegetante del callo dell'utero senza cura chirurgica. Ginecologia. 1912;9:82-88.

28. Pack GT. Note of the experimental use of rabies vaccine for melanomatosis. Arch Dermtol Syphilol. 1950;62:694-695.

29. Southam CM. Present status of oncolytic virus studies. Trans NY Acad Sci. 1960;22:657-673.

30. Asada T. Treatment of human cancer with mumps virus. Cancer. 1974;34:1907-1928. 
31. Yamanishi $\mathrm{K}$, Takahashi $\mathrm{M}$, Kurimura $\mathrm{T}$, Ueda $\mathrm{S}$, Minekawa Y. Studies on live mumps virus vaccine. 3. Evaluation of newly developed live mumps virus vaccine. Biken J. 1970;13:157-161.

32. Moore AE. Carcinolytic viruses. In: RJC H, ed. Biological Approaches to Cancer Chemotherapy. New York: Academic Press; 1961: 365-370.

33. Harris JE, Sinkovics JG. The Immunology of Malignant Disease. St Louis, Mosby; 1976 pp. 180-182, 464-467, 475-478.

34. Hoster HA, Zanes RP, von Haam E. Studies in Hodgkin's syndrome. Can Res. 1949;9:473-480.

35. Southam CM, Moore AE. Clinical studies of viruses as antineoplastic agents with particular reference to Egypt 101 virus. Cancer. 1952;5:1025-1034.

36. Huebner RJ, Rowe WP, Schatten WE, Smith RR, Thomas LB. Studies on the use of viruses in the treatment of carcinoma of the cervix. Cancer. 1956;9:1211-1218.

37. Russell SJ. Replicating vectors for gene therapy of cancer: risks, limitations and prospects. Eur $J$ Cancer. 1994;30A:1165-1171.

38. Csatary L, Gergely P. Vaccine therapy of malignant tumors. Orv Hetil. 1990;131:2585-2588.

39. Csatary LK, Eckhardt S, Bukosza I, et al. Attenuated veterinary virus vaccine for the treatment of cancer. Cancer Detect Prev. 1993;17:619-627.

40. Shimizu Y, Hasumi K, Okudaira Y, Yamanishi K, Takahashi M. Immunotherapy of advanced gynecologic cancer patients utilizing mumps virus. Cancer Detect Prev. 1988;12:487-495.

41. Okuno Y, Asada T, Yamanishi K, et al. Studies on the use of mumps virus for treatment of human cancer. Biken $J$. 1978;21:37-49.

42. Heicappell R, Schirrmacher V, von Hoegen P, Ahlert T, Appelhans B. Prevention of metastatic spread by postoperative immunotherapy with virally modified autologous tumor cells. I. Parameters for optimal therapeutic effects. Int $J$ Cancer. 1986;37:569-577.

43. Boone CW. Augmented immunogenicity of tumor cell homogenates infected with influenza virus. Can Res. 1974;47:394-400.

44. Ioannides CG, Platsoucas CD, Patenia R, et al. T-cell functions in ovarian cancer patients treated with viral oncolysates: I. Increased helper activity to immunoglobulins production. Anticancer Res. 1990;10:645-653.

45. Horvath JC, Pritchard M, Vega V, Sinkovics JG. The viral oncolysate story and its expansion toward dendritic cell vaccines. In: Oncolytic Viruses as Cancer Therapeutics. Banff, Alberta; 2003: 45.

46. Lechner MS, Mack DH, Finicle AB, Crook T, Vousden $\mathrm{KH}$, Laimins LA. Human papillomavirus E6 proteins bind p53 in vivo and abrogate p53-mediated repression of transcription. EMBO J. 1992;11:3045-3052.

47. Gannon JV, Lane DP. p53 and DNA polymerase alpha compete for binding to SV40T antigen. Nature. 1987;329:456-458.

48. Goodrum FD, Ornelles DA. The early region 1B 55kilodalton oncoprotein of adenovirus relieves growth restrictions imposed on viral replication by the cell cycle. J Virol. 1997;71:548-561.

49. Hall AR, Dix BR, O'Carroll SJ, Braithwaite AW. p53dependent cell death/apoptosis is required for a productive adenovirus infection. Nat Med. 1998;4:1068-1072.

50. Turnell AS, Grand RJ, Gallimore PH. The replicative capacities of large E1B-null group $\mathrm{A}$ and group $\mathrm{C}$ adenoviruses are independent of host cell p53 status. J Virol. 1999;73:2074-2083.
51. Goodrum FD, Ornelles DA. p53 status does not determine outcome of E1B 55-kilodalton mutant adenovirus lytic infection. $J$ Virol. 1998;72:9479-9490.

52. Harada JN, Berk AJ. p53-Independent and -dependent requirements for E1B-55K in adenovirus type 5 replication. J Virol. 1999;73:5333-5344.

53. Kirn D, Hermiston T, McCormick F. ONYX-015: clinical data are encouraging. Nat Med. 1998;4:1341-1342.

54. Rothmann T, Hengstermann A, Whitaker NJ, Scheffner M, zur Hausen H. Replication of ONYX-015, a potential anticancer adenovirus, is independent of p53 status in tumor cells. J Virol. 1998;72:9470-9478.

55. Habib NA, Mitry RR, Sarraf CE. Assessment of growth inhibition and morphological changes in in vitro and in vivo hepatocellular carcinoma models post treatment with d11520 adenovirus. Cancer Gene Ther. 2002;9:414-420.

56. Kenney S, Pagano JS. Viruses as oncolytic agents: a new age for "therapeutic" viruses? J Natl Cancer Inst. 1994:86:1185-1186.

57. Yang Y, Nunes FA, Berencsi K, Furth EE, Gonczol E, Wilson JM. Cellular immunity to viral antigens limits E1deleted adenoviruses for gene therapy. Proc Natl Acad Sci USA. 1994;91:4407-4411.

58. Nemunaitis J, Ganly I, Khuri F, et al. Selective replication and oncolysis in p53 mutant tumors with ONYX-015, an E1B-55kD gene-deleted adenovirus, in patients with advanced head and neck cancer: a phase II trial. Cancer Res. 2000;60:6359-6366.

59. Ganly I, Kirn D, Eckhardt G, et al. A phase I study of Onyx-015, an E1B attenuated adenovirus, administered intratumorally to patients with recurrent head and neck cancer. Clin Cancer Res. 2000;6:798-806.

60. Nemunaitis J, Khuri F, Ganly I, et al. Phase II trial of intratumoral administration of ONYX-015, a replicationselective adenovirus, in patients with refractory head and neck cancer. J Clin Oncol. 2001;19:289-298.

61. Khuri FR, Nemunaitis J, Ganly I, et al. a controlled trial of intratumoral ONYX-015, a selectively-replicating adenovirus, in combination with cisplatin and 5-fluorouracil in patients with recurrent head and neck cancer. Nat Med. 2000;6:879-885.

62. Vasey PA, Shulman LN, Campos S, et al. Phase I trial of intraperitoneal injection of the E1B-55-kD-gene-deleted adenovirus ONYX-015 (d11520) given on days 1 through 5 every 3 weeks in patients with recurrent/refractory epithelial ovarian cancer. $J$ Clin Oncol. 2002;20: $1562-1569$.

63. Nemunaitis J, Cunningham C, Tong AW, et al. Pilot trial of intravenous infusion of a replication-selective adenovirus (ONYX-015) in combination with chemotherapy or IL-2 treatment in refractory cancer patients. Cancer Gene Ther. 2003;10:341-352.

64. Habib N, Salama H, Abd El Latif Abu Median A, et al. Clinical trial of E1B-deleted adenovirus (d11520) gene therapy for hepatocellular carcinoma. Cancer Gene Ther. 2002;9:254-259.

65. Reid T, Galanis E, Abbruzzese J. Intra-arterial administration of a replication-selective adenovirus (d11520) in patients with colorectal carcinoma metastatic to the liver: a phase I trial. Gene Therapy. 2001;8:1618-1626.

66. Nemunaitis J, Cunningham C, Buchanan A, et al. Intravenous infusion of a replication-selective adenovirus (ONYX-015) in cancer patients: safety, feasibility and biological activity. Gene Therapy. 2001;8:746-759.

67. Mulvihill S, Warren R, Venook A, et al. Safety and feasibility of injection with an E1B-55 kDa gene-deleted, 
replication-selective adenovirus (ONYX-015) into primary carcinomas of the pancreas: a phase I trial. Gene Therapy. 2001;8:308-315.

68. Reid T, Galanis E, Abbruzzese J, et al. Hepatic arterial infusion of a replication-selective oncolytic adenovirus (d11520): phase II viral, immunologic, and clinical endpoints. Cancer Res. 2002;62:6070-6079.

69. Hecht JR, Bedford R, Abbruzzese JL, et al. A phase I/II trial of intratumoral endoscopic ultrasound injection of ONYX-015 with intravenous gemcitabine in unresectable pancreatic carcinoma. Clin Cancer Res. 2003;9:555-561.

70. Hamid O, Varterasian ML, Wadler S, et al. Phase II trial of intravenous CI-1042 in patients with metastatic colorectal cancer. J Clin Oncol. 2003;21:1498-1504.

71. Makower D, Rozenblit A, Kaufman H, et al. Phase II clinical trial of intralesional administration of the oncolytic adenovirus ONYX-015 in patients with hepatobiliary tumors with correlative p53 studies. Clin Cancer Res. 2003;9:693-702.

72. Bai M, Harfe B, Freimuth P. Mutations that alter an ArgGly-Asp (RGD) sequence in the adenovirus type 2 penton base protein abolish its cell-rounding activity and delay virus reproduction in flat cells. $J$ Virol. 1993;67:5198-5205.

73. Wickham TJ, Mathias P, Cheresh DA, Nemerow GR. Integrins alpha $\mathrm{v}$ beta 3 and alpha $\mathrm{v}$ beta 5 promote adenovirus internalization but not virus attachment. Cell. 1993;73:309-319.

74. Huang S, Kamata T, Takada Y, Ruggeri ZM, Nemerow GR. Adenovirus interaction with distinct integrins mediates separate events in cell entry and gene delivery to hematopoietic cells. J Virol. 1996;70:4502-4508.

75. Bergelson JM, Cunningham JA, Droguett G. Isolation of a common receptor for Coxsackie B viruses and adenoviruses 2 and 5. Science. 1997;275:1320-1323.

76. Bergelson JM. Receptors mediating adenovirus attachment and internalization. Biochem Pharmacol. 1999;57:975-979.

77. Tomko RP, Xu R, Philipson L. HCAR and MCAR: the human and mouse cellular receptors for subgroup C adenoviruses and group B coxsackieviruses. Proc Natl Acad Sci USA. 1997;94:3352-3356.

78. Davison E, Diaz RM, Hart IR, Santis G, Marshall JF. Integrin alpha5beta1-mediated adenovirus infection is enhanced by the integrin-activating antibody TS2/16. J Virol. 1997;71:6204-6207.

79. FitzGerald DJ, Padmanabhan R, Pastan I, Willingham MC. Adenovirus-induced release of epidermal growth factor and pseudomonas toxin into the cytosol of $\mathrm{KB}$ cells during receptor-mediated endocytosis. Cell. 1983;32: 607-617.

80. Seth P, Willingham MC, Pastan I. Adenovirus-dependent release of $51 \mathrm{Cr}$ from $\mathrm{KB}$ cells at an acidic $\mathrm{pH}$. J Biol Chem. 1984;259:14350-14353.

81. Greber UF, Webster P, Weber J, Helenius A. The role of the adenovirus protease on virus entry into cells. $E M B O$ J. 1996;15:1766-1777.

82. Greber UF, Suomalainen M, Stidwill RP, Boucke K, Ebersold MW, Helenius A. The role of the nuclear pore complex in adenovirus DNA entry. EMBO J. 1997;16: 5998-6007.

83. Leopold PL, Ferris B, Grinberg I, Worgall S, Hackett NR, Crystal RG. Fluorescent virions: dynamic tracking of the pathway of adenoviral gene transfer vectors in living cells. Hum Gene Ther. 1998;9:367-378.

84. Wang K, Huang S, Kapoor-Munshi A, Nemerow G. Adenovirus internalization and infection require dynamin. J Virol. 1998;72:3455-3458.
85. Suomalainen M, Nakano MY, Keller S, Boucke K, Stidwill RP, Greber UF. Microtubule-dependent plusand minus end-directed motilities are competing processes for nuclear targeting of adenovirus. J Cell Biol. 1999;144: $657-672$.

86. Wisnivesky JP, Leopold PL, Crystal RG. Specific binding of the adenovirus capsid to the nuclear envelope. Hum Gene Ther. 1999;10:2187-2195.

87. Leopold PL, Kreitzer G, Miyazawa N. Dynein- and microtubule-mediated translocation of adenovirus serotype 5 occurs after endosomal lysis. Hum Gene Ther. 2000;11:151-165.

88. Saphire AC, Guan T, Schirmer EC, Nemerow GR, Gerace L. Nuclear import of adenovirus DNA in vitro involves the nuclear protein import pathway and hsc70. J Biol Chem. 2000;275:4298-4304.

89. Yeh P, Perricaudet M. Advances in adenoviral vectors: from genetic engineering to their biology. FASEB $J$. 1997;11:615-623.

90. Wold WS, Doronin K, Toth K, Kuppuswamy M, Lichtenstein DL, Tollefson AE. Immune responses to adenoviruses: viral evasion mechanisms and their implications for the clinic. Curr Opin Immunol. 1999;11:380-386.

91. Mahr JA, Gooding LR. Immune evasion by adenoviruses. Immunol Rev. 1999;168:121-130.

92. Flint J, Shenk T. Viral transactivating proteins. Annu Rev Genet. 1997;31:177-212.

93. Nemunaitis J. Oncolytic viruses. Invest New Drugs 1999; 17:375-386.

94. Rancourt C, Piche A, Gomez-Navarro J, et al. Interleukin6 modulated conditionally replicative adenovirus as an antitumor/cytotoxic agent for cancer therapy. Clin Cancer Res. 1999;5:43-50.

95. Howe JA, Demers GW, Johnson DE, et al. Evaluation of E1-mutant adenoviruses as conditionally replicating agents for cancer therapy. Mol Ther. 2000;2:485-495.

96. Kratzer F, Rosorius $\mathrm{O}$, Heger $\mathrm{P}$, et al. The adenovirus type 5 E1B-55K oncoprotein is a highly active shuttle protein and shuttling is independent of E4orf6, p53 and Mdm2. Oncogene. 2000;19:850-857.

97. Wold WS, Hermiston TW, Tollefson AE. Adenovirus proteins that subvert host defenses. Trends Microbiol. 1994;2:437-443

98. Wold WS, Tollefson AE, Hermiston TW. E3 transcription unit of adenovirus. Curr Top Microbiol Immunol. 1995;199(Part 1):237-274.

99. Horwitz MS, Tufariello J, Grunhaus A, Fejer G. Model systems for studying the effects of adenovirus E3 genes on virulence in vivo. Curr Top Microbiol Immunol. 1995;199(Part 3):195-211.

100. Lee MG, Abina MA, Haddada H, Perricaudet M. The constitutive expression of the immunomodulatory gp19k protein in E1-, E3-adenoviral vectors strongly reduces the host cytotoxic $\mathrm{T}$ cell response against the vector. Gene Therapy. 1995;2:256-262.

101. Bett AJ, Haddara W, Prevec L, Graham FL. An efficient and flexible system for construction of adenovirus vectors with insertions or deletions in early regions 1 and 3. Proc Natl Acad Sci USA. 1994;91:8802-8806.

102. Ilan Y, Droguett G, Chowdhury NR. Insertion of the adenoviral E3 region into a recombinant viral vector prevents antiviral humoral and cellular immune responses and permits long-term gene expression. Proc Natl Acad Sci USA. 1997;94:2587-2592

103. Braithwaite AW, Russell IA. Induction of cell death by adenoviruses. Apoptosis. 2001;6:359-370. 
104. Tollefson AE, Scaria A, Hermiston TW, Ryerse JS, Wold LJ, Wold WS. The adenovirus death protein (E3-11.6K) is required at very late stages of infection for efficient cell lysis and release of adenovirus from infected cells. $J$ Virol. 1996;70:2296-2306.

105. McCart JA, Puhlmann M, Lee J. Complex interactions between the replicating oncolytic effect and the enzyme/ prodrug effect of vaccinia-mediated tumor regression. Gene Therapy. 2000;7:1217-1223.

106. Hawkins LK, Hermiston T. Gene delivery from the E3 region of replicating human adenovirus: evaluation of the E3B region. Gene Therapy. 2001;8:1142-1148.

107. Wang Y, Hallden G, Hill R, et al. E3 gene manipulations affect oncolytic adenovirus activity in immunocompetent tumor models. Nat Biotechnol. 2003;21:1328-1335.

108. Elkon KB, Liu CC, Gall JG, et al. Tumor necrosis factor alpha plays a central role in immune-mediated clearance of adenoviral vectors. Proc Natl Acad Sci USA. 1997;94:9814-9819.

109. Benihoud K, Saggio I, Opolon P. Efficient, repeated adenovirus-mediated gene transfer in mice lacking both tumor necrosis factor alpha and lymphotoxin alpha. $J$ Virol. 1998;72:9514-9525.

110. Alcami A, Koszinowski UH. Viral mechanisms of immune evasion. Immunol Today. 2000;21:447-455.

111. Nash P, Barrett J, Cao JX, et al. Immunomodulation by viruses: the myxoma virus story. Immunol Rev. 1999;168:103-120.

112. Smith GL, Symons JA, Khanna A, Vanderplasschen A, Alcami A. Vaccinia virus immune evasion. Immunol Rev. 1997;159:137-154.

113. Smith VP, Bryant NA, Alcami A. Ectromelia, vaccinia and cowpox viruses encode secreted interleukin-18-binding proteins. J Gen Virol. 2000;81:1223-1230.

114. Spriggs MK. One step ahead of the game: viral immunomodulatory molecules. Annu Rev Immunol. 1996;14: 101-130.

115. Saraiva M, Alcami A. CrmE, a novel soluble tumor necrosis factor receptor encoded by poxviruses. $J$ Virol. 2001;75:226-233.

116. Nemunaitis J, Edelman J. Selectively replicating viral vectors. Cancer Gene Ther. 2002;9:987-1000.

117. Reid T, Sze D, Galanis E. Intra-arterial administration of a replication-selective adenovirus ONYX-015 in patients with colorectal carcinoma metastatic to the liver: safety, feasibility and biological activity. (abstr 793). Proc Am Soc Clin Oncol. 2003;22:198.

118. Rahman A, Tsai V, Goudreau A. Specific depletion of human anti-adenovirus antibodies facilitates transduction in an in vivo model for systemic gene therapy. Mol Ther. 2001;3:768-778

119. Li E, Stupack D, Bokoch GM, Nemerow GR. Adenovirus endocytosis requires actin cytoskeleton reorganization mediated by Rho family GTPases. J Virol. 1998;72: 8806-8812.

120. Wolff G, Worgall S, van Rooijen N, Song WR, Harvey BG, Crystal RG. Enhancement of in vivo adenovirusmediated gene transfer and expression by prior depletion of tissue macrophages in the target organ. $J$ Virol. 1997;71:624-629.

121. Biewenga J, van der Ende MB, Krist LF, Borst A, Ghufron M, van Rooijen N. Macrophage depletion in the rat after intraperitoneal administration of liposome-encapsulated clodronate: depletion kinetics and accelerated repopulation of peritoneal and omental macrophages by administration of Freund's adjuvant. Cell Tissue Res. 1995;280:189-196.
122. McCuskey RS, McCuskey PA, Urbaschek R, Urbaschek B. Kupffer cell function in host defense. Rev Infect Dis. 1987;9(Suppl 5):S616-619.

123. Huitinga I, Ruuls SR, Jung S, Van Rooijen N, Hartung HP, Dijkstra CD. Macrophages in T cell line-mediated, demyelinating, and chronic relapsing experimental autoimmune encephalomyelitis in Lewis rats. Clin Exp Immunol. 1995;100:344-351.

124. Laman JD, Kors N, Van Rooijen N, Claassen E. Mechanism of follicular trapping: localization of immune complexes and cell remnants after elimination and repopulation of different spleen cell populations. Immunology. 1990;71:57-62.

125. Pinto AJ, Stewart D, van Rooijen N, Morahan PS. Selective depletion of liver and splenic macrophages using liposomes encapsulating the drug dichloromethylene diphosphonate: effects on antimicrobial resistance. J Leukocyte Biol. 1991;49:579-586.

126. Qian Q, Jutila MA, Van Rooijen N, Cutler JE. Elimination of mouse splenic macrophages correlates with increased susceptibility to experimental disseminated candidiasis. J Immunol. 1994;152:5000-5008.

127. Tschaikowsky K, Brain JD. Effects of liposome-encapsulated dichloromethylene diphosphonate on macrophage function and endotoxin-induced mortality. Biochim Biophys Acta. 1994;1222:323-330.

128. Van Rooijen N. The liposome-mediated macrophage 'suicide' technique. J Immunol Methods. 1989;124:1-6.

129. van Rooijen N, Kors N, Kraal G. Macrophage subset repopulation in the spleen: differential kinetics after liposome-mediated elimination. $J$ Leukocyte Biol. 1989;45:97-104.

130. Van Rooijen N, Kors N, vd Ende M, Dijkstra CD. Depletion and repopulation of macrophages in spleen and liver of rat after intravenous treatment with liposomeencapsulated dichloromethylene diphosphonate. Cell Tissue Res. 1990;260:215-222.

131. Van Rooijen N, Sanders A. Liposome mediated depletion of macrophages: mechanism of action, preparation of liposomes and applications. $J$ Immunol Methods. 1994;174:83-93.

132. Van Rooijen N, Sanders A. Kupffer cell depletion by liposome-delivered drugs: comparative activity of intracellular clodronate, propamidine, and ethylenediaminetetraacetic acid. Hepatology. 1996;23:1239-1243.

133. Vreden SG, Sauerwein RW, Verhave JP, Van Rooijen N, Meuwissen JH, Van Den Broek MF. Kupffer cell elimination enhances development of liver schizonts of Plasmodium berghei in rats. Infect Immun. 1993;61:1936-1939.

134. Lorence RM, Roberts MS, Groene WS, Rabin H. Replication-competent, oncolytic Newcastle disease virus for cancer therapy. Monogr Virol (Basel, Karger). 2001;22:160-182.

135. Jordan MA, Toso RJ, Thrower D, Wilson L. Mechanism of mitotic block and inhibition of cell proliferation by taxol at low concentrations. Proc Natl Acad Sci USA. 1993;90:9552-9556.

136. Long BH, Fairchild CR. Paclitaxel inhibits progression of mitotic cells to G1 phase by interference with spindle formation without affecting other microtubule functions during anaphase and telephase. Cancer Res. 1994;54: 4355-4361.

137. Adams JD, Flora KP, Goldspiel BR, Wilson JW, Arbuck SG, Finley R. Taxol: a history of pharmaceutical development and current pharmaceutical concerns. J Natl Cancer Inst Monogr. 1993;15:141-147. 
138. Kohn KW, Jackman J, O'Connor PM. Cell cycle control and cancer chemotherapy. J Cell Biochem. 1994;54: 440-452.

139. Edelman MJ, Gandara DR. Promising new agents in the treatment of non-small cell lung cancer. Cancer Chemother Pharmacol. 1996;37:385-393.

140. Ikeda K, Ichikawa $\mathrm{T}$, Wakimoto $\mathrm{H}$, et al. Oncolytic virus therapy of multiple tumors in the brain requires suppression of innate and elicited antiviral responses. Nat Med. 1999;5:881-887.

141. Li Y, Pong RC, Bergelson JM, et al. Loss of adenoviral receptor expression in human bladder cancer cells: a potential impact on the efficacy of gene therapy. Cancer Res. 1999;59:325-330.

142. Miller CR, Buchsbaum DJ, Reynolds PN, et al. Differential susceptibility of primary and established human glioma cells to adenovirus infection: targeting via the epidermal growth factor receptor achieves fiber receptorindependent gene transfer. Cancer Res. 1998;58: 5738-5748.

143. Fechner $\mathrm{H}$, Wang $\mathrm{X}$, Wang $\mathrm{H}$, et al. Trans-complementation of vector replication versus Coxsackie-adenovirusreceptor overexpression to improve transgene expression in poorly permissive cancer cells. Gene Therapy. 2000;7: 1954-1968.

144. Cripe TP, Dunphy EJ, Holub AD, et al. Fiber knob modifications overcome low, heterogeneous expression of the coxsackievirus-adenovirus receptor that limits adenovirus gene transfer and oncolysis for human rhabdomyosarcoma cells. Cancer Res. 2001;61:2953-2960.

145. Mori T, Arakawa H, Tokino T, Mineura K, Nakamura Y. Significant increase of adenovirus infectivity in glioma cell lines by extracellular domain of hCAR. Oncol Res. 1999;11:513-521.

146. Dmitriev I, Krasnykh V, Miller CR, et al. An adenovirus vector with genetically modified fibers demonstrates expanded tropism via utilization of a coxsackievirus and adenovirus receptor-independent cell entry mechanism. J Virol. 1998;72:9706-9713.

147. Kelly FJ, Miller CR, Buchsbaum DJ, et al. Selectivity of TAG-72-targeted adenovirus gene transfer to primary ovarian carcinoma cells versus autologous mesothelial cells in vitro. Clin Cancer Res. 2000;6:4323-4333.

148. Vanderkwaak TJ, Wang M, Gomez-Navarro J, et al. An advanced generation of adenoviral vectors selectively enhances gene transfer for ovarian cancer gene therapy approaches. Gynecol Oncol. 1999;74:227-234.

149. Kasono K, Blackwell JL, Douglas JT, et al. Selective gene delivery to head and neck cancer cells via an integrin targeted adenoviral vector. Clin Cancer Res. 1999;5: 2571-2579.

150. Hemmi S, Geertsen R, Mezzacasa A, Peter I, Dummer R. The presence of human coxsackievirus and adenovirus receptor is associated with efficient adenovirus-mediated transgene expression in human melanoma cell cultures. Hum Gene Ther. 1998;9:2363-2373.

151. Li D, Duan L, Freimuth P, O'Malley Jr BW. Variability of adenovirus receptor density influences gene transfer efficiency and therapeutic response in head and neck cancer. Clin Cancer Res. 1999;5:4175-4181.

152. Khuu H, Conner M, Vanderkwaak T, et al. Detection of Coxsackie-adenovirus receptor (CAR) immunoreactivity in ovarian tumors of epithelial derivation. Appl Immunohistochem Mol Morphol. 1999;7:266-270.

153. Heinicke T, Hemmi S, Mauer D, Sauerbruch T, Caselman WH. Transduction efficiency of adenoviral vectors in colorectal cancer cells is determined by the presence of the coxsackie adenovirus receptor. Mol Ther. 2000;1:S60.

154. Dodson J, DeMarzo A, Schoenberg M, et al. Coxsackie adenovirus receptor immunohistochemical staining in superficial bladder tumors. In: American Society of Gene Therapy Third Annual Meeting. Denver, CO: Mol Ther. 2000: S59.

155. Okegawa T, Li Y, Pong RC, Bergelson JM, Zhou J, Hsieh JT. The dual impact of coxsackie and adenovirus receptor expression on human prostate cancer gene therapy. Cancer Res. 2000;60:5031-5036.

156. Anders M, Ding RX, Lipner EM, Balmain A, McCormick F, Korn WM. Inhibition of the MAPK pathway upregulates the human Coxsackie and adenovirus receptor (CAR) and increases the infectivity of cancer cells with adenoviruses. Proc Am Assoc Cancer Res. 2001;42:703.

157. Douglas JT, Rogers BE, Rosenfeld ME, Michael SI, Feng M, Curiel DT. Targeted gene delivery by tropism-modified adenoviral vectors. Nat Biotechnol. 1996;14:1574-1578.

158. Blackwell JL, Miller CR, Douglas JT, et al. Retargeting to EGFR enhances adenovirus infection efficiency of squamous cell carcinoma. Arch Otolaryngol Head Neck Surg. 1999; $125: 856-863$.

159. Haisma HJ, Grill J, Curiel DT, et al. Targeting of adenoviral vectors through a bispecific single-chain antibody. Cancer Gene Ther. 2000;7:901-904.

160. Dmitriev I, Kashentseva E, Rogers BE, Krasnykh V, Curiel DT. Ectodomain of coxsackievirus and adenovirus receptor genetically fused to epidermal growth factor mediates adenovirus targeting to epidermal growth factor receptor-positive cells. J Virol. 2000;74:6875-6884.

161. Grill J, Van Beusechem VW, Van Der Valk P, et al, Combined targeting of adenoviruses to integrins and epidermal growth factor receptors increases gene transfer into primary glioma cells and spheroids. Clin Cancer Res. 2001;7:641-650.

162. Haisma HJ, Pinedo HM, Rijswijk A, et al. Tumor-specific gene transfer via an adenoviral vector targeted to the pancarcinoma antigen EpCAM. Gene Therapy. 1999;6: 1469-1474.

163. Goldman CK, Rogers BE, Douglas JT, et al. Targeted gene delivery to Kaposi's sarcoma cells via the fibroblast growth factor receptor. Cancer Res. 1997;57:1447-1451.

164. Rogers BE, Douglas JT, Sosnowski BA, et al. Enhanced in vivo gene delivery to human ovarian cancer xenografts utilizing a tropism-modified adenovirus vector. Tumor Targeting. 1998;3:25-31.

165. Rancourt C, Rogers BE, Sosnowski BA, et al. Basic fibroblast growth factor enhancement of adenovirusmediated delivery of the herpes simplex virus thymidine kinase gene results in augmented therapeutic benefit in a murine model of ovarian cancer. Clin Cancer Res. 1998;4:2455-2461.

166. Gu DL, Gonzalez AM, Printz MA, et al. Fibroblast growth factor 2 retargeted adenovirus has redirected cellular tropism: evidence for reduced toxicity and enhanced antitumor activity in mice. Cancer Res. 1999;59:2608-2614.

167. Printz MA, Gonzalez AM, Cunningham M, et al. Fibroblast growth factor 2-retargeted adenoviral vectors exhibit a modified biolocalization pattern and display reduced toxicity relative to native adenoviral vectors. Hum Gene Ther. 2000;11:191-204.

168. Rogers BE, Douglas JT, Ahlem C, Buchsbaum DJ, Frincke J, Curiel DT. Use of a novel cross-linking method to modify adenovirus tropism. Gene Therapy. 1997;4:1387-1392. 
169. Grandis JR, Melhem MF, Barnes EL, Tweardy DJ. Quantitative immunohistochemical analysis of transforming growth factor-alpha and epidermal growth factor receptor in patients with squamous cell carcinoma of the head and neck. Cancer. 1996;78:1284-1292.

170. Alemany R, Suzuki K, Curiel DT. Blood clearance rates of adenovirus type 5 in mice. J Gen Virol. 2000;81:2605-2609.

171. Tao N, Gao GP, Parr M, et al. Sequestration of adenoviral vector by Kupffer cells leads to a nonlinear dose response of transduction in liver. Mol Ther. 2001;3:28-35.

172. Wu H, Seki T, Dmitriev I, et al. Double modification of adenovirus fiber with RGD and polylysine motifs improves coxsackievirus-adenovirus receptor-independent gene transfer efficiency. Hum Gene Ther. 2002;13:1647-1653.

173. Bucheit AD, Kumar S, Grote DM, et al. An oncolytic measles virus engineered to enter cells through the CD20 antigen. Mol Ther. 2003;7:62-72.

174. Peng KW, Donovan KA, Schneider U, Cattaneo R, Lust JA, Russell SJ. Oncolytic measles viruses displaying a single-chain antibody against CD38, a myeloma cell marker. Blood. 2003;101:2557-2562.

175. Schneider U, von Messling V, Devaux P, Cattaneo R. Efficiency of measles virus entry and dissemination through different receptors. J Virol. 2002;76:7460-7467.

176. Stojdl DF, Lichty B, Knowles S, et al. Exploiting tumor-specific defects in the interferon pathway with a previously unknown oncolytic virus. Nat Med. 2000;6: $821-825$

177. Bangma $\mathrm{CH}$. Targeting of adenoviral vectors for gene therapy of prostate cancer. Prostate Cancer Prostatic Dis. 2000;3:308-312.

178. Barnett BG, Tillman BW, Curiel DT, Douglas JT. Dual targeting of adenoviral vectors at the levels of transduction and transcription enhances the specificity of gene expression in cancer cells. Mol Ther. 2002;6:377-385.

179. Liu FF. Novel gene therapy approach for nasopharyngeal carcinoma. Semin Cancer Biol. 2002;12:505-515.

180. Logg CR, Logg A, Matusik RJ, Bochner BH, Kasahara N. Tissue-specific transcriptional targeting of a replicationcompetent retroviral vector. J Virol. 2002;76:12783-12791.

181. Nahde T, Muller K, Fahr A, Muller R, Brusselbach S. Combined transductional and transcriptional targeting of melanoma cells by artificial virus-like particles. J Gene Med. 2001;3:353-361.

182. Qiao J, Doubrovin M, Sauter BV, et al. Tumor-specific transcriptional targeting of suicide gene therapy. Gene Therapy. 2002;9:168-175.

183. Savontaus MJ, Sauter BV, Huang TG, Woo SL. Transcriptional targeting of conditionally replicating adenovirus to dividing endothelial cells. Gene Therapy. 2002;9:972-979.

184. Gromeier M, Lachmann S, Rosenfeld MR, Gutin PH, Wimmer E. Intergeneric poliovirus recombinants for the treatment of malignant glioma. Proc Natl Acad Sci USA. 2000;97:6803-6808.

185. DeWeese TL, van der Poel H, Li S, et al. A phase I trial of CV706, a replication-competent, PSA selective oncolytic adenovirus, for the treatment of locally recurrent prostate cancer following radiation therapy. Cancer Res. 2001;61:7464-7472.

186. Hallenbeck PL, Chang YN, Hay C, et al. A novel tumorspecific replication-restricted adenoviral vector for gene therapy of hepatocellular carcinoma. Hum Gene Ther. 1999; 10:1721-1733.

187. Lee F, Mulligan R, Berg P, Ringold G. Glucocorticoids regulate expression of dihydrofolate reductase cDNA in mouse mammary tumour virus chimaeric plasmids. Nature. 1981;294:228-232.

188. Walther W, Wendt J, Stein U. Employment of the mdr1 promoter for the chemotherapy-inducible expression of therapeutic genes in cancer gene therapy. Gene Therapy. 1997:4:544-552.

189. Vile RG, Hart IR. In vitro and in vivo targeting of gene expression to melanoma cells. Cancer Res. 1993;53: 962-967.

190. Morelli AE, Larregina AT, Smith-Arica J, et al. Neuronal and glial cell type-specific promoters within adenovirus recombinants restrict the expression of the apoptosisinducing molecule Fas ligand to predetermined brain cell types, and abolish peripheral liver toxicity. J Gen Virol. 1999;80(Part 3):571-583.

191. Gao Z, Fields JZ, Boman BM. Tumor-specific expression of anti-mdr1 ribozyme selectively restores chemosensitivity in multidrug-resistant colon-adenocarcinoma cells. Int $J$ Cancer. 1999;82:346-352.

192. Hernandez-Alcoceba R, Pihalja M, Wicha MS, Clarke MF. A novel, conditionally replicative adenovirus for the treatment of breast cancer that allows controlled replication of E1a-deleted adenoviral vectors. Hum Gene Ther. 2000;11:2009-2024.

193. Steele C, Sacks PG, Adler-Storthz K, Shillitoe EJ. Effect on cancer cells of plasmids that express antisense RNA of human papillomavirus type 18. Cancer Res. 1992;52: 4706-4711.

194. Thompson EM, Nagata S, Tsuji FI. Vargula hilgendorfii luciferase: a secreted reporter enzyme for monitoring gene expression in mammalian cells. Gene. 1990;96:257-262.

195. Gibson SA, Pellenz C, Hutchison RE, Davey FR, Shillitoe EJ. Induction of apoptosis in oral cancer cells by an antibcl-2 ribozyme delivered by an adenovirus vector. Clin Cancer Res. 2000;6:213-222.

196. Kim E, Kim JH, Shin HY, et al. Ad-mTERT-delta19, a conditional replication-competent adenovirus driven by the human telomerase promoter, selectively replicates in and elicits cytopathic effect in a cancer cell-specific manner. Hum Gene Ther. 2003;14:1415-1428.

197. Rodriguez R, Schuur ER, Lim HY, Henderson GA, Simons JW, Henderson DR. Prostate attenuated replication competent adenovirus (ARCA) CN706: a selective cytotoxic for prostate-specific antigen-positive prostate cancer cells. Cancer Res. 1997;57:2559-2563.

198. Kawakami K, Kawakami M, Joshi BH, Puri RK. Interleukin-13 receptor-targeted cancer therapy in an immunodeficient animal model of human head and neck cancer. Cancer Res. 2001;61:6194-6200.

199. Husak P, Ho K, Aimi J, et al. Circulating oncolytic and wild type adenovirus levels in clinical trial patients treated with CG7870. In: Ther M, ed. Sixth Annual Meeting of the American Society of Gene Therapy. Washington, DC: Elsevier; 2003: S315.

200. DeWeese T, Arterbery E, Michalski J, et al. A Phase I/II dose escalation trial of the intra prostatic injection of CG7870, a prostate specific antigen-dependent oncolytic adenovirus in patients with locally recurrent prostate cancer following definitive radiotherapy. In: Ther M, ed. Sixth Annual Meeting of the American Society of Gene Therapy. Washington, DC: Elsevier; 2003: S446.

201. Li Y, McCadden J, Ferrer F, et al. Prostate-specific expression of the diphtheria toxin A chain (DT-A): studies of inducibility and specificity of expression of prostatespecific antigen promoter-driven DT-A adenoviralmediated gene transfer. Cancer Res. 2002;62:2576-2582. 
202. Pang S. Targeting and eradicating cancer cells by a prostate-specific vector carrying the diphtheria toxin A gene. Cancer Gene Ther. 2000;7:991-996.

203. Lee G, Hong HJ, You YO, Bang EH, Kook JK, Min BM. Effect of p53 gene transfer on the cell proliferation and cell cycle progression in a human oral cancer cell line with p53 mutations. Int J Oral Biol. 1998;23:189-199.

204. Robert MS, Lorence RM, Gronen WS, et al. Treatment of neoplasms with viruses. In: International Patent Publication No 9/18799. 1999.

205. Pecora AL, Rizvi N, Cohen GI, et al. Phase I trial of intravenous administration of PV701, an oncolytic virus, in patients with advanced solid cancers. $J$ Clin Oncol. 2002;20:2251-2266

206. Schirrmacher V, Ahlert T, Probstle T, et al. Immunization with virus-modified tumor cells. Semin Oncol. 1998;25: 677-696.

207. Batliwalla FM, Bateman BA, Serrano D, et al. A 15-year follow-up of AJCC stage III malignant melanoma patients treated postsurgically with Newcastle disease virus (NDV) oncolysate and determination of alterations in the CD8T cell repertoire. Mol Med. 1998;4:783-794.

208. Cassel WA, Garrett RE. Newcastle disease virus as an antineoplastic agent. Cancer. 1965;18:863-868.

209. Cassel WA, Murray DR, Phillips HS. A phase II study on the postsurgical management of stage II malignant melanoma with a Newcastle disease virus oncolysate. Cancer. 1983;52:856-860.

210. Cassel WA, Murray DR. A ten-year follow-up on stage II malignant melanoma patients treated postsurgically with Newcastle disease virus oncolysate. Med Oncol Tumor Pharmacother. 1992;9:169-171.

211. Cassel WA, Murray DR. Treatment of stage II malignant melanoma patients with a Newcastle disease virus oncolysate. Nat Immun Cell Growth Regul. 1988;7:351-352.

212. Sinkovics J, Horvath J. New developments in the virus therapy of cancer: a historical review. Intervirology. 1993;36:193-214.

213. Schlag P, Manasterski M, Gerneth T, et al. Active specific immunotherapy with Newcastle-disease-virus-modified autologous tumor cells following resection of liver metastases in colorectal cancer. First evaluation of clinical response of a phase II trial. Cancer Immunol Immunother. 1992;35:325-330.

214. Kirchner HH, Anton P, Atzpodien J. Adjuvant treatment of locally advanced renal cancer with autologous virusmodified tumor vaccines. World J Urol. 1995;13:171-173.

215. Haas C, Strauss G, Moldenhauer G, Iorio RM, Schirrmacher V. Bispecific antibodies increase T-cell stimulatory capacity in vitro of human autologous virus-modified tumor vaccine. Clin Cancer Res. 1998;4:721-730.

216. Lorence RM, Reichard KW, Katubig BB, et al. Complete regression of human neuroblastoma xenografts in athymic mice after local Newcastle disease virus therapy. $J$ Natl Cancer Inst. 1994;86:1228-1233.

217. Lorence RM, Katubig BB, Reichard KW, et al. Complete regression of human fibrosarcoma xenografts after local Newcastle disease virus therapy. Cancer Res. 1994;54:6017-6021.

218. Lorence RM, Roberts MS, Groene WS, et al. Regression of human tumor xenografts following intravenous treatment using PV70, a naturally attenuated oncolytic strain of Newcastle disease virus (Abstract 2442). Proc Am Assoc Cancer Res. 2001;42:454.

219. Mineta T, Rabkin SD, Martuza RL. Treatment of malignant gliomas using ganciclovir-hypersensitive, ribo- nucleotide reductase-deficient herpes simplex viral mutant. Cancer Res. 1994;54:3963-3966.

220. Chase M, Chung RY, Chiocca EA. An oncolytic viral mutant that delivers the CYP2B1 transgene and augments cyclophosphamide chemotherapy. Nat Biotechnol. 1998; 16:444-448.

221. Boviatsis EJ, Scharf JM, Chase M, et al. Antitumor activity and reporter gene transfer into rat brain neoplasms inoculated with herpes simplex virus vectors defective in thymidine kinase or ribonucleotide reductase. Gene Therapy. 1994;1:323-331.

222. Varghese S, Rabkin SD. Oncolytic herpes simplex virus vectors for cancer virotherapy. Cancer Gene Ther. 2002;9:967-978.

223. Chou J, Kern ER, Whitley RJ, Roizman B. Mapping of herpes simplex virus-1 neurovirulence to gamma 134.5, a gene nonessential for growth in culture. Science. 1990;250:1262-1266.

224. Chou J, Roizman B. The gamma 1(34.5) gene of herpes simplex virus 1 precludes neuroblastoma cells from triggering total shutoff of protein synthesis characteristic of programed cell death in neuronal cells. Proc Natl Acad Sci USA. 1992;89:3266-3270.

225. McKie EA, MacLean AR, Lewis AD, et al. Selective in vitro replication of herpes simplex virus type 1 (HSV-1) ICP34.5 null mutants in primary human CNS tumours evaluation of a potentially effective clinical therapy. $\mathrm{Br} J$ Cancer. 1996;74:745-752.

226. Martuza RL. Act locally, think globally. Nat Med. 1997;3:1323.

227. Alemany R, Gomez-Manzano C, Balague C, et al. Gene therapy for gliomas: molecular targets, adenoviral vectors, and oncolytic adenoviruses. Exp Cell Res. 1999;252:1-12.

228. Pennisi E. Will a twist of viral fate lead to a new cancer treatment? Science. 1996;274:342-343.

229. Mineta T, Rabkin SD, Yazaki T, Hunter WD, Martuza RL. Attenuated multi-mutated herpes simplex virus-1 for the treatment of malignant gliomas. Nat Med. 1995;1: 938-943.

230. Andreansky SS, He B, Gillespie GY, et al. The application of genetically engineered herpes simplex viruses to the treatment of experimental brain tumors. Proc Natl Acad Sci USA. 1996;93:11313-11318.

231. Chambers R, Gillespie GY, Soroceanu L, et al. Comparison of genetically engineered herpes simplex viruses for the treatment of brain tumors in a SCID mouse model of human malignant glioma. Proc Natl Acad Sci USA. 1995;92:1411-1415.

232. Kesari S, Randazzo BP, Valyi-Nagy T, et al. Therapy of experimental human brain tumors using a neuroattenuated herpes simplex virus mutant. Lab Invest. 1995;73: 636-648.

233. Lambright ES, Kang EH, Force S, et al. Effect of preexisting anti-herpes immunity on the efficacy of herpes simplex viral therapy in a murine intraperitoneal tumor model. Mol Ther. 2000;2:387-393.

234. Randazzo BP, Bhat MG, Kesari S, Fraser NW, Brown SM. Treatment of experimental subcutaneous human melanoma with a replication-restricted herpes simplex virus mutant. J Invest Dermatol. 1997;108:933-937.

235. Toda M, Rabkin SD, Martuza RL. Treatment of human breast cancer in a brain metastatic model by G207, a replication-competent multimutated herpes simplex virus 1 . Hum Gene Ther. 1998;9:2177-2185.

236. Toda M, Rabkin SD, Kojima H, Martuza RL. Herpes simplex virus as an in situ cancer vaccine for the induction 
of specific anti-tumor immunity. Hum Gene Ther. 1999;10:385-393.

237. Yoon SS, Carroll NM, Chiocca EA, Tanabe KK. Cancer gene therapy using a replication-competent herpes simplex virus type 1 vector. Ann Surg. 1998;228:366-374.

238. Coukos G, Makrigiannakis A, Kang EH, et al. Use of carrier cells to deliver a replication-selective herpes simplex virus-1 mutant for the intraperitoneal therapy of epithelial ovarian cancer. Clin Cancer Res. 1999;5:1523-1537.

239. Lambright ES, Caparrelli DJ, Abbas AE, et al. Oncolytic therapy using a mutant type- 1 herpes simplex virus and the role of the immune system. Ann Thorac Surg. 1999;68:1756-1760 (discussion 1761-1752).

240. Cozzi PJ, Burke PB, Bhargav A, et al. Oncolytic viral gene therapy for prostate cancer using two attenuated, replication-competent, genetically engineered herpes simplex viruses. Prostate. 2002;53:95-100.

241. Coukos G, Rubin SC, Molnar-Kimber KL. Application for recombinant herpes simplex virus-1 (HSV-1) for the treatment of malignancies outside the central nervous system. Gene Ther Mol Biol. 1999;3:79-89.

242. Kucharczuk JC, Randazzo B, Chang MY, et al. Use of a "replication-restricted" herpes virus to treat experimental human malignant mesothelioma. Cancer Res. 1997;57: 466-471.

243. Toyoizumi T, Mick R, Abbas AE, Kang EH, Kaiser LR, Molnar-Kimber KL. Combined therapy with chemotherapeutic agents and herpes simplex virus type 1 ICP34.5 mutant (HSV-1716) in human non-small cell lung cancer. Hum Gene Ther. 1999;10:3013-3029.

244. Advani SJ, Chung SM, Yan SY, et al. Replicationcompetent, nonneuroinvasive genetically engineered herpes virus is highly effective in the treatment of therapy-resistant experimental human tumors. Cancer Res. 1999;59: 2055-2058.

245. Carroll NM, Chiocca EA, Takahashi K, Tanabe KK Enhancement of gene therapy specificity for diffuse colon carcinoma liver metastases with recombinant herpes simplex virus. Ann Surg. 1996;224:323-329 (discussion 329-330).

246. Bennett JJ, Delman KA, Burt BM, et al. Comparison of safety, delivery, and efficacy of two oncolytic herpes viruses (G207 and NV1020) for peritoneal cancer. Cancer Gene Ther. 2002;9:935-945.

247. Markert JM, Medlock MD, Rabkin SD, et al. Conditionally replicating herpes simplex virus mutant, G207 for the treatment of malignant glioma: results of a phase I trial. Gene Therapy. 2000;7:867-874.

248. Rampling R, Cruickshank G, Papanastassiou V, et al. Toxicity evaluation of replication-competent herpes simplex virus (ICP 34.5 null mutant 1716) in patients with recurrent malignant glioma. Gene Therapy. 2000;7:859-866.

249. Papanastassiou V, Rampling R, Fraser M, et al. The potential for efficacy of the modified (ICP 34.5(-)) herpes simplex virus HSV1716 following intratumoural injection into human malignant glioma: a proof of principle study. Gene Therapy. 2002;9:398-406.

250. MacKie RM, Stewart B, Brown SM. Intralesional injection of herpes simplex virus 1716 in metastatic melanoma. Lancet. 2001;357:525-526.

251. Han ZQ, Hu J, Liu B, et al. Combination of OncoVEX with chemotherapy for cancer treatment. Mol Ther. 2003; 7:S288

252. Liu B, Robinson M, Han Z, et al. Optimised oncolytic herpes simplex virus for cancer treatment. Mol Ther. 2003; 7:S293.
253. Hu J, McNeish I, Shorrock C, et al. A phase I clinical trial with OncoVEXGMCSF. Mol Ther. 2003;7:S447.

254. Meignier B, Longnecker R, Roizman B. In vivo behavior of genetically engineered herpes simplex viruses R7017 and R7020: construction and evaluation in rodents. $J$ Infect Dis. 1988;158:602-614.

255. Wong RJ, Kim SH, Joe JK, Shah JP, Johnson PA, Fong Y. Effective treatment of head and neck squamous cell carcinoma by an oncolytic herpes simplex virus. $\mathrm{J} \mathrm{Am} \mathrm{Coll}$ Surg. 2001;193:12-21.

256. Meignier B, Martin B, Whitley RJ, Roizman B. In vivo behavior of genetically engineered herpes simplex viruses R7017 and R7020. II. Studies in immunocompetent and immunosuppressed owl monkeys (Aotus trivirgatus). J Infect Dis. 1990;162:313-321.

257. Todo T, Ebright MI, Fong T, et al. Oncolytic herpes simplex virus (G207) therapy: from basic to clinical. In: Maruta H, ed. Tumor-Suppressing Viruses, Genes, and Drugs. San Diego: Academic Press; 2002: 45-75.

258. Coen DM, Goldstein DJ, Weller SK. Herpes simplex virus ribonucleotide reductase mutants are hypersensitive to acyclovir. Antimicrob Agents Chemother. 1989;33: 1395-1399.

259. MacLean AR, ul-Fareed M, Robertson L, Harland J, Brown SM. Herpes simplex virus type 1 deletion variants 1714 and 1716 pinpoint neurovirulence-related sequences in Glasgow strain $17+$ between immediate early gene 1 and the 'a' sequence. J Gen Virol. 1991;72(Part 3):631-639.

260. Robinson M, Liu B, Han Z, et al. ICP34.5 deleted herpes simplex virus 1 with enhanced oncolytic and anti-tumor properties: preclinical studies. Mol Ther. 2002;5:S319.

261. Todo T, Rabkin SD, Sundaresan P, et al. Systemic antitumor immunity in experimental brain tumor therapy using a multimutated, replication-competent herpes simplex virus. Hum Gene Ther. 1999;10:2741-2755.

262. Endo T, Toda M, Watanabe $\mathrm{M}$, et al. In situ cancer vaccination with a replication-conditional HSV for the treatment of liver metastasis of colon cancer. Cancer Gene Ther. 2002;9:142-148.

263. Toda M, Martuza RL, Kojima H, Rabkin SD. In situ cancer vaccination: an IL-12 defective vector/replicationcompetent herpes simplex virus combination induces local and systemic antitumor activity. $J$ Immunol. 1998;160:4457-4464.

264. Carew JF, Kooby DA, Halterman MW, Kim SH, Federoff HJ, Fong Y. A novel approach to cancer therapy using an oncolytic herpes virus to package amplicons containing cytokine genes. Mol Ther. 2001;4:250-256.

265. Todo T, Martuza RL, Dallman MJ, Rabkin SD. In situ expression of soluble B7-1 in the context of oncolytic herpes simplex virus induces potent antitumor immunity. Cancer Res. 2001;61:153-161

266. Wong RJ, Patel SG, Kim S, et al. Cytokine gene transfer enhances herpes oncolytic therapy in murine squamous cell carcinoma. Hum Gene Ther. 2001;12:253-265.

267. Bennett JJ, Malhotra S, Wong RJ, et al. Interleukin 12 secretion enhances antitumor efficacy of oncolytic herpes simplex viral therapy for colorectal cancer. Ann Surg. 2001;233:819-826.

268. Parker JN, Gillespie GY, Love CE, Randall S, Whitley RJ, Markert JM. Engineered herpes simplex virus expressing IL-12 in the treatment of experimental murine brain tumors. Proc Natl Acad Sci USA. 2000;97:2208-2213.

269. Jorgensen TJ, Katz S, Wittmack EK, et al. Ionizing radiation does not alter the antitumor activity of herpes simplex virus vector G207 in subcutaneous tumor models 
of human and murine prostate cancer. Neoplasia. 2001;3:451-456.

270. Chahlavi A, Todo T, Martuza RL, Rabkin SD. Replication-competent herpes simplex virus vector G207 and cisplatin combination therapy for head and neck squamous cell carcinoma. Neoplasia. 1999;1:162-169.

271. Advani SJ, Sibley GS, Song PY, et al. Enhancement of replication of genetically engineered herpes simplex viruses by ionizing radiation: a new paradigm for destruction of therapeutically intractable tumors. Gene Therapy. 1998;5:160-165.

272. Bradley JD, Kataoka Y, Advani S, et al. Ionizing radiation improves survival in mice bearing intracranial high-grade gliomas injected with genetically modified herpes simplex virus. Clin Cancer Res. 1999;5:1517-1522.

273. Chung SM, Advani SJ, Bradley JD, et al. The use of a genetically engineered herpes simplex virus (R7020) with ionizing radiation for experimental hepatoma. Gene Therapy. 2002;9:75-80.

274. Blank SV, Rubin SC, Coukos G, Amin KM, Albelda SM, Molnar-Kimber KL. Replication-selective herpes simplex virus type 1 mutant therapy of cervical cancer is enhanced by low-dose radiation. Hum Gene Ther. 2002;13: 627-639.

275. Spear MA, Sun F, Eling DJ, et al. Cytotoxicity, apoptosis, and viral replication in tumor cells treated with oncolytic ribonucleotide reductase-defective herpes simplex type 1 virus (hrR3) combined with ionizing radiation. Cancer Gene Ther. 2000;7:1051-1059.

276. Coukos G, Makrigiannakis A, Kang EH, Rubin SC, Albelda SM, Molnar-Kimber KL. Oncolytic herpes simplex virus-1 lacking ICP34.5 induces p53-independent death and is efficacious against chemotherapy-resistant ovarian cancer. Clin Cancer Res. 2000;6:3342-3353.

277. Pawlik TM, Nakamura H, Yoon SS, et al. Oncolysis of diffuse hepatocellular carcinoma by intravascular administration of a replication-competent, genetically engineered herpesvirus. Cancer Res. 2000;60:2790-2795.

278. Nakamura H, Mullen JT, Chandrasekhar S, Pawlik TM, Yoon SS, Tanabe KK. Multimodality therapy with a replication-conditional herpes simplex virus 1 mutant that expresses yeast cytosine deaminase for intratumoral conversion of 5-fluorocytosine to 5-fluorouracil. Cancer Res. 2001;61:5447-5452.

279. Miyatake S, Martuza RL, Rabkin SD. Defective herpes simplex virus vectors expressing thymidine kinase for the treatment of malignant glioma. Cancer Gene Ther. 1997;4:222-228.

280. Aghi M, Chou TC, Suling K, Breakefield XO, Chiocca EA. Multimodal cancer treatment mediated by a replicating oncolytic virus that delivers the oxazaphosphorine/rat cytochrome P450 2B1 and ganciclovir/herpes simplex virus thymidine kinase gene therapies. Cancer Res. 1999;59:3861-3865.

281. Todo T, Rabkin SD, Martuza RL. Evaluation of ganciclovir-mediated enhancement of the antitumoral effect in oncolytic, multimutated herpes simplex virus type 1 (G207) therapy of brain tumors. Cancer Gene Ther. 2000;7:939-946.

282. Miyatake S, Iyer A, Martuza RL, Rabkin SD. Transcriptional targeting of herpes simplex virus for cell-specific replication. J Virol. 1997;71:5124-5132.

283. Miyatake SI, Tani S, Feigenbaum F, et al. Hepatomaspecific antitumor activity of an albumin enhancer/ promoter regulated herpes simplex virus in vivo. Gene Therapy. 1999;6:564-572.
284. Yamamura H, Hashio M, Noguchi M, et al. Identification of the transcriptional regulatory sequences of human calponin promoter and their use in targeting a conditionally replicating herpes vector to malignant human soft tissue and bone tumors. Cancer Res. 2001;61: 3969-3977.

285. Coffey MC, Strong JE, Forsyth PA, Lee PW. Reovirus therapy of tumors with activated Ras pathway. Science. 1998;282:1332-1334.

286. Hirasawa K, Yoon C, Nishikawa SG, Waisman DM, Lee PW. Reovirus therapy of metastatic cancer models in immune-competent mice. Proc Am Assoc Cancer Res. 2001;42:2427.

287. Hirasawa K, Nishikawa SG, Norman KL, Alain T, Kossakowska A, Lee PW. Oncolytic reovirus against ovarian and colon cancer. Cancer Res. 2002;62:1696-1701.

288. Morris DG, Forsyth PA, Paterson KF, et al. A phase I clinical trial evaluating intralesional Reolysin (reovirus) in histologically confirmed malignancies. In: American Society of Clinical Oncology. Orlando, FL: J Clin Oncol. 2002 (abstract 92).

289. Gomella LG, Mastrangelo MJ, McCue PA, Maguire HJ, Mulholland SG, Lattime EC. Phase i study of intravesical vaccinia virus as a vector for gene therapy of bladder cancer. J Urol. 2001;166:1291-1295.

290. Mastrangelo MJ, Maguire Jr HC, Eisenlohr LC, et al. Intratumoral recombinant GM-CSF-encoding virus as gene therapy in patients with cutaneous melanoma. Cancer Gene Ther. 1999;6:409-422.

291. Mukherjee S, Haenel T, Himbeck R, et al. Replicationrestricted vaccinia as a cytokine gene therapy vector in cancer: persistent transgene expression despite antibody generation. Cancer Gene Ther. 2000;7:663-670.

292. Wallack MK, Bash JA, Leftheriotis E, et al. Positive relationship of clinical and serologic responses to vaccinia melanoma oncolysate. Arch Surg. 1987;22:1460-1463.

293. Wallack MK, Scoggin SD, Sivanandham M. Active specific immunotherapy with vaccinia melanoma oncolysate. Mt Sinai J Med. 1992;59:227-233.

294. Wallack MK, Sivanandham M, Balch CM, et al. Surgical adjuvant active specific immunotherapy for patients with stage III melanoma: the final analysis of data from a phase III, randomized, double-blind, multicenter vaccinia melanoma oncolysate trial. J Am Coll Surg. 1998;187:69-77 (discussion 77-69).

295. Scoggin SD, Sivanandham M, Sperry RG, Wallack MK. Active specific adjuvant immunotherapy with vaccinia melanoma oncolysate. Ann Plast Surg. 1992;28:108-109.

296. van Ophoven A, Gitlitz B, Tso CL, et al. Phase I dose escalation trials of vaccinia (VV)-MUC-1-IL-2 gene therapy in patients with advanced $\mathrm{MUC}-1+$ prostate cancer (CAP) and non small cell lung cancer (NSCLC) B In: American Society of Clinical Oncology. New Orleans, LA: J Clin Oncol. 2000 (abstract 1811).

297. Eder JP, Kantoff PW, Roper K, et al. A phase I trial of a recombinant vaccinia virus expressing prostate-specific antigen in advanced prostate cancer. Clin Cancer Res. 2000;6:1632-1638.

298. Gulley J, Chen AP, Dahut W, et al. Phase I study of a vaccine using recombinant vaccinia virus expressing PSA (rV-PSA) in patients with metastatic androgen-independent prostate cancer. Prostate. 2002;53:109-117.

299. Schutz A, Oertli D, Marti WR, et al. Immunogenicity of nonreplicating recombinant vaccinia expressing HLAA201 targeted or complete MART-1/Melan-A antigen. Cancer Gene Ther. 2001;8:655-661. 
300. Timiryasova TM, Chen B, Fodor I. Replication-deficient vaccinia virus gene therpay vector: evaluation of exogenous gene expression mediated by PUV-inactivated virus in glioma cells. J Gene Med. 2001;3:468-477.

301. Naik AM, Xu H, Alexander HR, et al. A mutant vaccinia virus with improved tumor selectivity. Proceedings of the 54th Annual SSO Cancer Symposium. Washington, DC; 2001: 40 .

302. Freund YR, Mirsalis JC, Fairchild DG, et al. Vaccination with a recombinant vaccinia vaccine containing the B7-1 co-stimulatory molecule causes no significant toxicity and enhances $\mathrm{T}$ cell-mediated cytotoxicity. Int $J$ Cancer. 2000;85:508-517.

303. Shankar P, Schlom J, Hodge JW. Enhanced activation of rhesus $\mathrm{T}$ cells by vectors encoding a triad of costimulatory molecules (B7-1, ICAM-1, LFA-3). Vaccine. 2001;20:744-755.

304. Kalus RM, Kantor JA, Gritz L, et al. The use of combination vaccinia vaccines and dual-gene vaccinia vaccines to enhance antigen-specific T-cell immunity via T-cell costimulation. Vaccine. 1999;17:893-903.

305. Freytag SO, Khil M, Stricker H, et al. Phase I study of replication-competent adenovirus-mediated double suicide gene therapy for the treatment of locally recurrent prostate cancer. Cancer Res. 2002;62:4968-4976.

306. Rogulski KR, Wing MS, Paielli DL, Gilbert JD, Kim JH, Freytag SO. Double suicide gene therapy augments the antitumor activity of a replication-competent lytic adenovirus through enhanced cytotoxicity and radiosensitization. Hum Gene Ther. 2000;11:67-76.

307. Johnson L, Shen A, Boyle L, et al. Selectively replicating adenoviruses targeting deregulated E2F activity are potent, systemic antitumor agents. Cancer Cell. 2002;1:325-337.

308. Zhan J, Gao Y, Wang W, et al. Tumor-specific intravenous gene delivery using oncolytic adenoviruses. Cancer Gene Ther. in press.
309. Dobrikova E, Florez P, Merrill M, Moore S, Gromeier M. Mechanism of tumor specific replication of oncolytic poliovirus recombinants. In: Oncolytic Viruses as Cancer Therapeutics. Banff, Alberta; 2003: 24.

310. Fernandez M, Obuchi M, Balachandran S, Barber GN. Defects in interferon signaling mediate virus-induced oncolysis. In: Oncolytic Viruses as Cancer Therapeutics. Banff, Alberta; 2003: 25.

311. Bergmann M, Rajtarova J, Sachet M, et al. Tumorassociated IFN resistance promotes oncolysis by influenza virus NS1-deletion mutants. In: Oncolytic Viruses as Cancer Therapeutics. Banff, Alberta; 2003: 26.

312. Peng K, Soeffker D, Myers R, et al. Biodistribution of oncolytic measles virus. In: Oncolytic Viruses as Cancer Therapeutics. Banff, Alberta; 2003: 30.

313. Nemunaitis J, Cunningham C, Senzer N, et al. Pilot trial of genetically modified, attenuated Salmonella expressing the $E$. coli cytosine deaminase gene in refractory cancer patients. Cancer Gene Ther. 2003;10:737-744.

314. Kirn D, Martuza RL, Zwiebel J. Replication-selective virotherapy for cancer: Biological principles, risk management and future directions. Nat Med. 2001;7:781-787.

315. Wold WS, Toth K, Tollefson AE, et al. Oncolytic adenovirus vectors that overexpress ADP. In: Oncolytic Viruses as Cancer Therapeutics. Banff, Alberta; 2003: 18.

316. Akiyama M, Roelvink PW, Einfeld DA, Kovesdi I, King $\mathrm{R}$, Wickham TJ. In vivo targeting of CAR- and integrinablated adenovirus vectors to tumors. In: Oncolytic Viruses as Cancer Therapeutics. Banff, Alberta; 2003: 12.

317. Fisher KD. Polymer-coated adenovirus can be programmed to infect cells using selected ligands and shows extended plasma circulation following intravenous injection. In: Oncolytic Viruses as Cancer Therapeutics. Banff, Alberta; 2003: 17 